\title{
2011s-14
}

\section{Dynamic Price Dependence of Canadian and International Art Markets: An Empirical Analysis}

Douglas J. Hodgson, Aylin Seçkin

\begin{tabular}{c}
\hline Série Scientifique \\
Scientific Series
\end{tabular}

Montréal

Janvier 2011

(C) 2011 Douglas J. Hodgson, Aylin Seçkin. Tous droits réservés. All rights reserved. Reproduction partielle permise avec citation du document source, incluant la notice $($.

Short sections may be quoted without explicit permission, if full credit, including (C) notice, is given to the source.
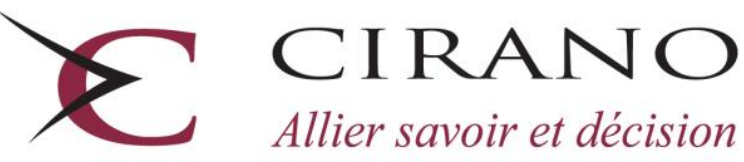

Allier savoir et décision

Centre interuniversitaire de recherche en analyse des organisations 


\section{CIRANO}

Le CIRANO est un organisme sans but lucratif constitué en vertu de la Loi des compagnies du Québec. Le financement de son infrastructure et de ses activités de recherche provient des cotisations de ses organisations-membres, d'une subvention d'infrastructure du Ministère du Développement économique et régional et de la Recherche, de même que des subventions et mandats obtenus par ses équipes de recherche.

CIRANO is a private non-profit organization incorporated under the Québec Companies Act. Its infrastructure and research activities are funded through fees paid by member organizations, an infrastructure grant from the Ministère du Développement économique et régional et de la Recherche, and grants and research mandates obtained by its research teams.

\section{Les partenaires du CIRANO}

Partenaire majeur

Ministère du Développement économique, de l'Innovation et de l'Exportation

\section{Partenaires corporatifs}

Banque de développement du Canada

Banque du Canada

Banque Laurentienne du Canada

Banque Nationale du Canada

Banque Royale du Canada

Banque Scotia

Bell Canada

BMO Groupe financier

Caisse de dépôt et placement du Québec

Fédération des caisses Desjardins du Québec

Financière Sun Life, Québec

Gaz Métro

Hydro-Québec

Industrie Canada

Investissements PSP

Ministère des Finances du Québec

Power Corporation du Canada

Raymond Chabot Grant Thornton

Rio Tinto

State Street Global Advisors

Transat A.T.

Ville de Montréal

\section{Partenaires universitaires}

École Polytechnique de Montréal

HEC Montréal

McGill University

Université Concordia

Université de Montréal

Université de Sherbrooke

Université du Québec

Université du Québec à Montréal

Université Laval

Le CIRANO collabore avec de nombreux centres et chaires de recherche universitaires dont on peut consulter la liste sur son site web.

Les cahiers de la série scientifique (CS) visent à rendre accessibles des résultats de recherche effectuée au CIRANO afin de susciter échanges et commentaires. Ces cahiers sont écrits dans le style des publications scientifiques. Les idées et les opinions émises sont sous l'unique responsabilité des auteurs et ne représentent pas nécessairement les positions du CIRANO ou de ses partenaires.

This paper presents research carried out at CIRANO and aims at encouraging discussion and comment. The observations and viewpoints expressed are the sole responsibility of the authors. They do not necessarily represent positions of CIRANO or its partners. 


\title{
Dynamic Price Dependence of Canadian and International Art Markets: An Empirical Analysis
}

\author{
Douglas J. Hodgson ", Aylin Seçkin ${ }^{\dagger}$
}

\begin{abstract}
Although the market for Canadian paintings is now of substantial magnitude, with several works having recently sold for well over a million dollars, it remains true that with very few exceptions, the works of Canadian painters are bought and sold only in Canada and held only by Canadian collectors. This market can thus be viewed as almost exclusively local, and it is therefore not clear that there should be any linkage between price movements for Canadian art and those for the mainstream international market in old master, impressionist, and modern art. This paper investigates the presence and nature of such time series dependence econometrically, both in terms of long term trends as reflected in the co-integrating relationship between Canadian and the international market, and in terms of short-run comovements as represented in correlations. The possibility that the local market "follows" the international one is also considered through an analysis of Granger-Causality. For Canadian art prices we use a new hedonic index that has been computed using an updated version of the data set of Hodgson and Vorkink (2004), while for the international prices, we use an index provided by Mei and Moses.
\end{abstract}

Mots clés : Alternative investments, Economics of art markets, Market for paintings, Time series analysis, CAPM.

Codes JEL : Z11, G11

\footnotetext{
* Département de sciences économiques, Université du Québec à Montréal, C.P. 8888, succ. Centre-Ville Montreal, Quebec, Canada, hodgson.douglas-james@uqam.ca.

${ }^{\dagger}$ Istanbul Bilgi University, Department of Economics, Kurtulus Deresi Cad. No:47 Dolapdere, Istanbul Turkey, e-mail: aseckin@bilgi.edu.tr.
} 


\section{Introduction}

It is common among those interested in the prices of art works to speak of "the" art market, as if there were one aggregate market for the many different categories of art that exist. However, due to the existence of different artistic media, national schools, historical periods, and individual artists, it is reasonable to suppose that art markets may be more or less segmented, with each segment following its own internal price dynamics, based on criteria related to the investors in the segment under consideration (whether it be due to particularities in the evolution of their economic fortunes or, indeed, of their tastes)

For an art collector who views their collection as being, at least in part, a significant financial investment, the design of an optimal art collection (or "portfolio") should take into account the overall risk and return combination of the collection, which may include several genres, categories and artists from different countries. For such a collector, it is important to understand the degree to which the changes in prices of the different components of the collection are likely to depend upon one another: the presence of art works from largely independent segments of the art market offers the possibility of risk diversification of an art market portfolio. ${ }^{1}$

It is thus of interest to have a measure of the degree of interdependence of price dynamics of different segments of the art market, and there is now a small literature that

\footnotetext{
1 There are a number of studies that examine the returns to investing in the works of painters from particular countries. See, for example, Arvin and Scigliano (2004), Hodgson and Vorkink (2004), and Hodgson (in press) for returns to Canadian painters' works; Higgs and Worthington (2005) for Australian painters' works; Agnello and Pierce (1996) on genre effects on American art investments; Edwards (2004) on Latin American paintings, and Mok, et al (1993) on the returns to modern Chinese paintings and Seckin and Atukeren (2006) on the returns to Turkish paintings.
} 
investigates various aspects of this question. Ginsburgh and Jeanfils (1995) find that price indices based on auction sales of major old master, impressionist, and modern European and American paintings sold in New York, London, and Paris, are cointegrated, and thus have shared long term price evolution, whether considered across artistic category or across cities and auction houses, with significant short-term interdependence also being present in returns. Worthington and Higgs (2003) analyze eight categories of major international art and find the presence of seven cointegratating relationships, and thus one sole common stochastic trend that drives the entire art market, indicating a very high degree of long-run uniformity in the market. They also find substantial short-run dependence to be present. These studies focus on segments of what we will refer to in the present paper as the mainstream international art market, and find these segments to be highly interdependent, so that, at this level, it is not inappropriate to speak of "the” art market.

The above findings suggest that the degree of diversification possible within a single collection of art works, viewed from a financial perspective, is limited. They also suggest that there is a commonality in the characteristics of collectors in the different segments of the mainstream market, whether it be due to personal economic circumstances, or to tastes, that has a similar impact on prices in all segments. It is of interest, both from the standpoint of portfolio diversification possibilities, as well as the more basic issue of economics of price formation and of tastes, to investigate the degree to which prices of art works not belonging to the international mainstream, particularly works from smaller or marginal national schools, are more or less dependent, statistically, on the mainstream market. Along these lines, Atukeren and Seckin (2009) examine the correlation and price dependence of Turkish and international art markets 
for the period 1990-2005. They find that despite any short-term fluctuations, prices in the Turkish and international art markets are cointegrated, and thus move together in the long-run, indicating a significant degree of integration (statistical and economic) of the Turkish and international markets..

Although the market for Canadian paintings is now of substantial magnitude, with several works having recently sold for well over a million dollars, it remains true that with very few exceptions, the works of Canadian painters are bought and sold only in Canada and held only by Canadian collectors. However, some of the most important Canadian collectors, such as the late Ken Thomson, who paid a record \$70 million for Rubens' "Massacre of the Innocents", are also highly active in the mainstream international market. For such an individual, or for any other collector interested in Canadian art, it is of interest to determine the degree to which this market can be viewed as mainly local, and to investigate the presence of linkages between price movements for Canadian art and those for the mainstream global market in old master, impressionist, and modern art.

An additional interest in an investigation of the degree of dependence of Canadian and mainstream markets stems from the findings of Hodgson and Vorkink (2004) that the risk-return relationship in the Canadian market is very similar to that found in many other studies of mainstream markets (see Worthington and Higgs (2003) and Atukeren and Seckin (2009) for surveys of the literature): viz., that the average rate of increase of art prices equals that of government bonds, whereas the variance of art price returns is of equal or greater magnitude than major stock index returns, and that the correlations between these two (the market "beta" of art prices) is very weakly positive. If the Canadian art market closely mimics the international market, the results of 
Hodgson and Vorkink (2004) would be as expected; however, if the dynamic of the Canadian art market is largely driven by internal factors independent of the international market, then the results of Hodgson and Vorkink (2004) would be of greater interest to those with a general interest in the question of art as an investment, as they would constitute fresh evidence on the nature of the risk-return relation in art markets, in effect providing a new "data point” in the literature.

In this paper, we examine the price dynamics between the Canadian and the international art markets. We first calculate the Canadian semi-annual art price index for the period 1968-2008. Then we test whether the prices of Canadian paintings move in line with or independently of the prices in the international art markets by means of cointegration and Granger-causality tests. 
We investigate the presence and nature of such time series dependence econometrically, both in terms of long term trends as reflected in the presence or absence of a co-integrating relationship between the Canadian and international markets, and in terms of short-run co-movements as represented by correlations. The possibility that the local market "follows" the international one is also considered through an analysis of the possible presence of Granger-Causality. The possibility that common economic fundamentals (or lack thereof) may account for common price movements is also investigated through the estimation of relationships between art prices and such fundamentals as general asset price indices and indices of real economic activity. For Canadian art prices we use a new hedonic index that has been computed using an updated version of the data set of Hodgson and Vorkink (2004), while for the international prices, we use an index provided by Mei and Moses (2002).

The rest of the paper is organized as follows. In section 2, we review the main results of the previous studies on financial returns in the Canadian art market. Then, we test for the time series properties of the Canadian paintings market price index and the Mei Moses Fine Art Prices index, calculated by Jienpeng Mei and Michael Moses, of Beautiful Asset Corporation, the semi-annual index available upon purchase at

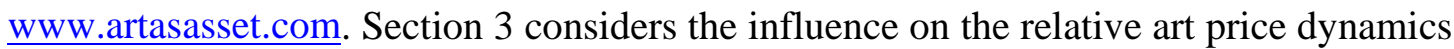
of aggregate indices of financial markets and general economic activity, and Section 4 concludes.

\section{A Time-series Analysis of the Relationship between Canadian and International} Art Markets 
We seek to investigate the degree of time series interdependence between Canadian and mainstream international art prices. We will begin by describing and analyzing the hedonic regression used to compute our new Canadian art index. We then present the international art price index as provided by Mei and Moses, and detailed results of our time series analysis of the joint dynamics of these two series follows.

\subsection{Data Description and Canadian Art Market}

Records of sales of Canadian paintings at auction from 1968 to 2008 were collected from Campbell (1970-75, 1980), Sotheby’s (1975, 1980) and Westbridge (1981-2008). Our data set includes results on sales for painters judged to be of significant interest from the standpoint of Canadian art history, this criterion being satisfied if a painter is mentioned in one of the major histories of Canadian art written by Harper (1977) or Reid (1973, 1988) ${ }^{2}$. We consider only oil and acrylic paintings, and only sales for which the auction house provides a secure attribution. For each painting, we recorded, in addition to the identity of the artist, the height and width, the medium and support, the auction house, the date of sale, the genre of the picture, and, when available, the date of execution of the painting. The prices we use are hammer prices as reported in the aforementioned publications. The resulting data set, an expanded version of that used by Hodgson and Vorkink (2004), contains 25,003 observations on final sales of 43 auction houses, covering the period 1968-2008, for 275 painters.

Painting in Canada has a long history, extending back to the seventeenth century and most Canadians are familiar with the names of several Canadian painters from a variety of historical periods and regions. ${ }^{3}$ There are many museums of Canadian art

\footnotetext{
${ }^{2}$ As the Mei-Moses international index, described below, includes primarily major international painters, we only want to include "major " Canadian painters here, effectively comparing "blue chip" with "blue chip".

${ }^{3}$ See Reid (1973).
} 
across the country, and major sales of art works (often in seven-digit figures) sometimes make headlines. Canadian art can be classified under three categories, namely, the colonial and early confederation period, the interwar nationalist period, and, thirdly, the post-war "International Contemporary" period. In addition, there are several First Nations artists included in our sample, and this category of art is an important and valuable (both financially and historically) component of Canadian art history and of the contemporary market. $^{4}$

Landscape and portraiture formed the backbone of Canadian art prior to the 1867 Confederation. Much of this work was produced to the demand of a small colonial elite of businessmen, officials and military officers by journeymen whose training would have seemed rudimentary by the standards of the leading European academicians of the day.

By the time of Confederation, sufficient demand had developed to provide employment for full-time, well-trained professional artists. Although imported art styles, especially from Paris, were influential, Canadian landscape painting (and photography) developed in the nineteenth century into a national art, largely patronized by eastern business leaders who were interested in the development of the new national territories. ${ }^{5}$ The art of the early Confederation period is characterized by painters generally working in styles heavily influenced by European academicism, old-fashioned by the standards of contemporary European advanced painting.

World War I helped Canada to strengthen its national identity and confidence. The growing development of a nationalistic Canadian consciousness during the 1910-20

\footnotetext{
4 Also of historical importance is the work of the early European cartographers who traversed and mapped the territories.

${ }^{5}$ See Reid (1979).
} 
period and after can be associated with a generation of Canadian painters who were consciously trying to create a distinctively indigenous idiom of painting, directly influenced by the Canadian landscape and not dependent on European styles. This outlook is most closely associated with the Group of Seven, who started painting together shortly before the war, in which many served as war artists, and who had their first formal group exhibition in 1920. During and after World War Two, the development of the most advanced Canadian artists came to parallel that of their American counterparts. In Montreal, a group of young artists influenced by European modernism, especially surrealism, were developing a form of abstract art not dissimilar from American abstract expressionism. The loosening of British ties led Canada to develop stronger economic, social and cultural relationship with its rich southern neighbor. The post-war development of the New York art world, with its associated critics and periodicals, had a rapid impact in Canada, in Montreal in particular.

\subsection{The Econometric Model}

The evolution of the Canadian auction market has been studied in a number of previous papers. While Hodgson and Vorkink (2004) estimate a price index for the art market in Canada for the period 1968-2001, Arvin and Scigliano (2004) consider only the paintings of Group of Seven sold at auctions. Valsan (2002) compares the pricing of paintings of several Canadian and American artists for the period 1987-1996 using nonparametric tests and the hedonic regression method.

This paper extends the hedonic price index presented in Hodgson and Vorkink (2004) by updating the data set until the first half of 2008. The hedonic regression helps address the question of regularities in art prices by including in the pricing function 
various characteristics (the genre, artist's name, technique, medium) of paintings such that the willingness to pay for each characteristic can be estimated.

The econometric model is written:

$$
p_{i}=\sum_{t=1}^{T} \gamma_{t} z_{i t}+\sum_{j=1}^{J} \alpha_{j} w_{i j}+u_{i}, i=1, \ldots, n,
$$

where $p_{i}$ is the logarithm of the price of sale $i$, the number of sales is $\mathrm{n}=25,003, z_{i t}$ is the value of a period-t dummy variable, equal to 1 if painting $i$ was sold in period $t$ and zero otherwise, with the number of time periods $T$ being 80 when the data are grouped semi-annually (1968:2-2008:1). Our estimates of the vector of associated parameters $\left\{\gamma_{t}\right\}_{t=1}^{T}$ will form our price index, to be used in the unit root and co-integration tests that we undertake in the following section.

The regressors $\left\{w_{i j}\right\}$ in (1) represent the characteristics of painting $i$. These include 274 painter dummies, 20 medium/support dummies, 42 auction house dummies, 8 genre dummies, height, width, surface area and a dummy for whether or not the work is dated, 428 regressors in total. One dummy in each category was omitted to avoid collinearity with the time period dummies, hence 274 painter dummies correspond to a set of 275 painters. Equation (1) can be re-written as follows:

$$
p_{i}=x_{i}^{\prime} \beta+u_{i}, i=1, \ldots ., n,
$$

where $x_{i}{ }^{\prime}=\left(z_{i 1}, \ldots, z_{i T}, w_{i 1}, \ldots, w_{i J}\right), \quad \beta=\left(\gamma_{1}, \ldots, \gamma_{T}, \alpha_{1}, \ldots, \alpha_{J}\right)^{\prime}$.

The time period dummies are used to compute rates of return. For example, the rate of return between period $t$ and $t+1$ can be written as follows:

$$
r_{t+1}=e^{\left(\gamma_{t+1}-\gamma_{t}\right)}-1
$$


To interpret the other regression parameter estimates, consider the dummies for painter. We omit the dummy for A.Y. Jackson from the regression (1), so that the dummy parameters $\alpha_{j}$ for each of the remaining painters will reflect their market values vis-àvis Jackson. The percentage difference between the value of a work by painter $j$ and a work by Jackson, controlling for all other factors, will be:

$$
e^{\alpha_{j}}-1
$$

One can estimate (1) and (2) using ordinary least squares (OLS). Under the standard assumptions, OLS will be consistent and asymptotically normal and will be asymptotically efficient if the disturbances are normally distributed. Due to efficiency concerns arising from the strong leptokurtosis found in the empirical error distribution we estimate (2) adaptively, following the technique of Bickel (1982), in order to obtain asymptotically efficient estimates when the distribution function of the disturbances $\left\{u_{i}\right\}$ is unknown. ${ }^{6}$

\subsection{Hedonic Price Index}

We initially consider the nominal returns in Canadian dollars. The semi-annual percentage changes in the hedonic price index for the Canadian paintings market for the 1968-2008 period in CAD dollar terms are presented in Table 1.

$<$ Table 1 approximately here >

Investing in paintings can be shown to have lower financial returns than stocks in Canada. This is in line with the general findings in the literature. The semi-annual dummy estimates are reported in Table 1 . For each period, we have provided the estimated dummy parameter, its standard error and the nominal returns. We observe a very high volatility prior to 1988 . This result is discussed by Hodgson and Vorkink

\footnotetext{
${ }^{6}$ See Hodgson and Vorkink (2004) for a detailed description of this method.
} 
(2004), and may partially be due to inefficient estimates stemming from relatively limited data availability in the earliest years of this period. However, it can also be attributed to the relative thinness of the Canadian art market during the early years together with general macroeconomic instability of world economies. The returns on the portfolio of Canadian paintings discussed above yielded around 19\% during the period 1969-2008(1). The average annual return between 1969 and 1980 is over $21 \%$, whereas the average annual nominal return between $1981-1991$ is less than $1 \%$. The average annual nominal return corresponding to the period $1992-2002$ was $4.76 \%$ and for the period 2003-08 it is around 13\%. The annual returns in the last period show a clear sign of appreciation of Canadian paintings; however, the returns are not as high as the ones generated in international art markets.

The top 25 list of painter dummy estimates of Hodgson and Vorkink (2004) seems to stay almost identical with the updated dataset (Table 2). The ranking is not necessarily significant. The reported standard errors permit us to interpret the significance of the parameter estimates relative to A.Y. Jackson. One major weakness of the hedonic method is that it is a reduced-form model that tells us nothing about supply and demand behavior in the art market. ${ }^{7}$

$<$ Table 2 approximately here $>$

Tom Thomson (1877-1917) is the number one artist in the art market. This result is not surprising since he is considered to be the most important painter in developing an original national style of Canadian landscape that inspired the Group of Seven, whose members are mostly in the top 25 list. $^{8}$ The top list also includes old masters such as

\footnotetext{
${ }^{7}$ See Velthius (2005), p.99. This point is also mentioned in Hodgson and Vorkink (2004).

8 The Group of Seven's founding members were Frank Carmichael, Lawren S.Harris, Fred Varley, A.J. Casson, J.E.H. MacDonald, A.Y. Jackson and Franz Johnston.
} 
William Berczy (1744-1813), James Duncan (1806-81), Jean Baptiste Roy-Audy (1778c.1848), Paul Kane (1810-71), and W.G.R. Hind (1833-89), whose works are mostly quite rare and of major historical importance. Detailed results on all the painters included in our study are reported in Table 3.

Some of the results for the remaining hedonic variables are reported in Tables 46. The medium and support have important effects on the price of a painting. Oil on canvas is considered as the most valuable type of medium-support combination such that for example paintings in the classification of oil on paper are priced 35\% less than an oil painting on canvas. In the Canadian art market, the paintings considered as genre scene and still life are priced $19 \%$ and $6.5 \%$ more relative to landscapes, respectively. A painting's price can be $15 \%$ higher if it is dated. The width and height contribute positively to price. However, as the area gets larger an extreme size painting may encounter some negative effects on its price.

\subsection{International Paintings Market}

Co-movements of international art prices are studied by Ginsburgh and Jeanfils (1995). They construct price indices on the basis of hedonic regressions using auction prices covering the period 1963-1992. They group paintings under three categories, Great Masters, Other Painters and US Painters, and collect auction data from three key art markets, London, Paris and New York. Using a VAR (vector autoregressive) model they show that art markets indeed move closely together. They also examine art and stock markets' short-run and long-run co-movements. Their findings confirm the absence of any long-run relation between art and stock markets but confirm the presence of short-run influences of stock markets on art prices. 
In this context, Worthington and Higgs (2003) examine the short-run and longrun linkages of prices among eight major painting categories and the global equity market for the period 1976-2001 using Artprice.com’s price indices. Worthington and Higgs's (2003) analysis basically focuses on the inner dynamics of the international paintings markets and their reactions to general financial market conditions. ${ }^{9}$

Worthington and Higgs (2003) employ multivariate co-integration procedures, Granger non-causality tests, level VARs, and generalized variance decomposition techniques to identify the presence (or lack thereof) and the degree of linkages among these markets. They find strong evidence for the high level of integration of international art markets for short as well as long time spans together with significant interrelationships between major stock markets and art markets.

For the international paintings market index we use the price index on international paintings calculated by Michael Moses and Jinpeing Mei (Mei Moses Fine Art Price index). They use the repeat-sales method in constructing their index. The indices are available on a semi-annual basis from mid-1969. They use over 13,000 repeat sale pairs under five categories: old master and 19th century, impressionist and modern, American before 1950, post war and contemporary, and Latin American. Although all sales in their sample occur in New York City, the results of Ginsburgh and Jeanfils (1995) cited above on the cointegration between New York auction prices and those of Paris and London for the same mainstream categories of international art justify, in our view, the use of the Mei-Moses index as a proxy for the mainstream international art market. The repeat sales and hedonic methods of index construction

\footnotetext{
${ }^{9}$ The painting categories included in Worthington and Higgs (2003) are: “contemporary masters”, "French impressionists”, “modern European”, “19 $19^{\text {th }}$ century European”, “old masters”, “Surrealists”, “20 $20^{\text {th }}$ century English”, and “modern US paintings”. They use Artprice data, www.artprice.com.
} 
both provide consistent estimates of the "true" underlying effect of time period on overall market prices. This fact, along with the fact that the nature of our Canadian art data set makes the application of the repeat-sales method impractical (it is almost impossible to identify more than a very small number of repeat sales base don our data source), justifies our comparative analysis of these two series. No serious problem should arise because they have been computed differently.

$<$ Figure 1 approximately here >

Figure 1 provides the graphs of MMFAI index together with the semi-annual Canadian art price index for the period 1969-2006 in log terms. Summary statistics are reported in Table 7. As can be seen, the international market for paintings displays four phases since 1969. The first period sees the rise of art prices especially starting from the early seventies until the end of the decade. ${ }^{10}$ The first oil shock of 1973 had its negative effect only in 1974, similarly the second oil shock in 1979 (however to a smaller extent) is associated with a small decrease in art prices. The second phase covers the eighties. The recession of 1981-82 had its impact on the sales prices but the recovery came fast and spectacular. The whole decade is characterized as the main art market bubble. Up until the early 1990s, the prices in the international art markets were increasing - mainly driven by demand from the Japanese who invested their gains from the high performing Japanese economy and the stock market in art. With the substantial downturn in the Japanese economy and stock market in the 1990s, art prices also fell, following the withdrawal of Japanese art collectors from world art markets. That is the beginning of the third phase and can be defined as the slowdown and continuous fall in international

\footnotetext{
${ }^{10}$ The graphs are in nominal terms. The same currency log real Mei-Moses art index and log real Canadian art price index as well as real returns of both indexes have been calculated. The related graphs are in the appendix.
} 
prices. This period runs to about the mid-nineties. The fourth and most recent phase includes the more or less continuous price increases from 1996 to 2006. This may be related to wealth effects stemming from the growth in the international economy and stock markets during this period ${ }^{11}$.

When we examine Figure 1, the first striking observation is that the Canadian art price index lags behind the Mei Moses Fine Art Index for almost the whole period (except 1980). An extremely high rate of return may be related to the composition of artists and works sold in that particular year, which needs further investigation. Another important point is that there seems to be closer comovement between the series in recent years. This observation can also be confirmed in Figure 2 where we observe the movement of both semi-annual nominal returns over the same period. The convergence of price movements, still a highly arguable observation, needs to be followed as more data become available. The true effect of the world economic and financial crisis on the international art prices would mostly be apparent by the end of 2009 .

Given the comparison of the developments and indices in the Canadian and international art markets, we now examine the relationships between the rate of returns of Canadian paintings and the returns of international art investments.

$<$ Figure 2 approximately here $>$

Comparing the returns in the international paintings market to those in the Canadian market, the Canadian market appears to have underperformed the international market. Another point to be mentioned is that the 1981-82 world economic slowdown hit the Canadian market more severely compared to the world markets. Also, the bursting of the art bubble of 1990 was less severe in Canada then elsewhere. This may

\footnotetext{
${ }^{11}$ Unfortunately our sample does not include the recent financial and economic crisis following the US mortgage crisis. The Canadian data for the first half of 2008 show a clear sign of a price drop.
} 
be related to the size of the Canadian market and its degree of integration with the main world market. Throughout the 1990's the returns of both indices show a weak relationship. However, from 2004 we see closer movements between the two series. This empirical observation needs to be further investigated.

We have also calculated real price indices and returns, in same-currency units. We have deflated the Mei Moses index using US Consumer Price Index (CPI), the Canadian index with the Canadian CPI, and then converted them to the same currency units using the Canada-US exchange rate. Graphs of the resulting real log index and real returns are shown below.

$<$ Figure 3 approximately here $>$

$<$ Figure 4 approximately here $>$

The graphs for log real indexes for Canadian Art and Mei-Moses fine art and real returns (same currency) are similar to the graphs expressed in nominal terms, although the relative weakness of returns in the Canadian market is even more pronounced in this case (this was period of general depreciation of the Canadian dollar) .

\subsection{Unit Root and Granger-causality Test Results}

It is well known in the econometrics literature that simple measures of statistical association do not imply causality; and that they may indeed turn out to be spurious. The search for unit roots in time series and the statistical methods to deal with integrated variables has been an important research area in macroeconomics since the 1980's. In view of this, we investigate the time-series properties of the Canadian paintings market price index and Mei and Moses global paintings market price index, (MMFAI). In doing so, we first test for the order of integration in the Canadian art index and the MMFAI series. If both indices are found to be I(1) processes, then we can proceed to test for co- 
integration. If the two series are found to be co-integrated, then it can be said that the two markets move together in the long run. We note that we will only report the results of our time series analysis as applied to the same-currency, real indices. The results are, in all cases, almost identical when the nominal own-currency indices are used, so these are omitted.

We test for the order of integration in the series using the augmented-DickeyFuller (1979) (ADF) and the Phillips and Perron (1988) (PP) tests on the natural logarithms of the variables and on the first differences. The results are reported in Table 7. It is standard in the literature to view art price indices as being a form of asset price series, and so being best modeled as martingales, and thus integrated of order one (possessing a unit root or stochastic trend). The findings of the time series analysis in the studies by Ginsburgh and Jeanfils (1995), Worthington and Higgs (2003), and Atukeren and Seckin (2009) are indeed consistent with this reasoning.

$<$ Table 7-a approximately here $>$

$<$ Table 7-b approximately here $>$

Our unit root tests are in accord with the literature in that both series are found to be best modeled as being integrated of order 1 (I(1)). In both cases, the ADF test applied to the index included a time trend and one autoregressive lag, with an intercept and one autoregressive lag being included in the test applied to the returns (no change in the results was obtained in considering lag orders up to six). In the case of the PP test, the deterministic regressors are as in the ADF tests, and the long-run variance of the autoregressive component is computed with a Parzen kernel and a bandwidth of one (no change in results was obtained in considering bandwidths up to six). The application of the BIC and AIC order selection criteria to the returns found that a model with no 
autoregressive lags fit both return series better than any $\operatorname{AR}(p)$ model for $p$ from 1 to 6 , supporting the martingale hypothesis for art price returns.

Given that both indices are well modeled as being I(1), and so possessing longrun stochastic trending components, we proceed to test for cointegration of the indices, in order to see if there is a common stochastic trend shared by the series, as has been found in other studies of multiple art markets. We apply the ADF and PP tests to the residuals of the OLS regression of the Canadian index on the international one. The tests are applied essentially as discussed above for the raw data.

$<$ Table 8 approximately here $>$

As seen from Table 8, neither test can reject the null that the series are not cointegrated at any conventional significance level. This finding is robust to the inclusion of up to six autoregressive lags in the ADF test and a bandwidth of up to six in the PP case. Canadian art prices are not responsive to the developments in the international art markets even in the long-run. This is counter-evidence to "the globalization of tastes” argument made by Goetzmann (1993).

The cointegration tests run counter to the existing literature, which has found that all segments of the art market so far studied do indeed share stochastic trends. This is not the case for the Canadian market, however. Its long run evolution follows its own course and its driving stochastic trend is different from the one driving other art markets. We consider this result to be noteworthy and it is discussed further below. However, we will terminate our analysis of the joint time series behavior of the two indices considered here by investigating the nature of the short run dependence that may or may not be exist between the returns series. 
Turning our attention to the nominal returns series, we find that the simple contemporaneous correlation coefficient between the returns to investing in the Canadian and the international paintings markets for the period of 1969-2006 is 0.1489 (Table 9). The volatility of the Canadian market is slightly higher than that of the global market. The standard deviations of the nominal returns in the Canadian and international markets are $13.29 \%$ and $12.74 \%$ respectively.

$<$ Tables 9 and 10 approximately here $>$

Similarly, the standard deviations of the real returns (same currency) in the Canadian and international paintings markets are $13.01 \%$ and $12.33 \%$ respectively. The simple contemporaneous correlation coefficient between the real returns to investing in the Canadian and the international paintings markets for the period of 1969-2006 is even smaller, 0.1069 (Table 10). Although there is some contemporaneous correlation between the series, it is quite weak, and much smaller than the correlation coefficient of 0.40 found by Atukeren and Seckin (2009) to exist between the Turkish and international indices.

We finish by exploring the presence of any short-run dynamic dependence between the return series through the application of tests of Granger-causality. This allows us to determine whether returns in either market "lead" those in the other. Supposing that international trends in art pricing are established by the mainstream international market, it is possible that this market Granger-causes the Canadian one. We would not expect to see returns in the Canadian market leading those in the international one. We have estimated the bivariate VAR for lag orders of one to six.

< Table 11 approximately here > 
The results of a Wald test of the null that one variable does not Granger-cause the other are provided in Table 11 . Note that the null asymptotic distribution of each statistic will be chi-squared with degrees of freedom equal to the number of lags. We do find that in the model with one lag, there is bidirectional Granger causality, so that changes in one price index do have some predictive power for the other, although this finding is not robust to the inclusion in the VAR of additional lags.

We can therefore conclude that the overall time series dependence between the Canadian and international markets is much weaker than has been found in the literature for all other studies of multiple art markets. There is no long-run dependence between the series, and the short-run dependence is limited to a small positive contemporaneous correlation and possibly some Granger-causality at one lag. In the rest of the paper, we discuss the possible interpretations and explanations for this finding, and investigate the explanatory power for the Canadian art index, over and above that of international art pries, of aggregate economic variables that would seem to be of relevance for art prices, such as aggregate income and wealth.

Since art investments are investments with longer horizons, long term wealth effects are presumably the principal economic determinant of art demand, along with art's portfolio diversification properties. One explanation for our finding that the Canadian art market largely goes its own way could be the differences in the aesthetic pleasure between Canadian and world art market participants. The effort of creating a national identity and having concentrated for several generations on landscapes and genre scenes paintings rather than abstract and conceptual art may have limited the size of the audience for Canadian art. Moreover, Canadian art markets could have been influenced by factors other than aesthetics. The social structure, communities and other 
cultural networks within the art markets in Canada may have structural differences relative to global art markets.

\section{Art Prices and Macroeconomic Indicators}

We next examine the degree to which Canadian paintings can be used to diversify an international investment portfolio. Our time series analyses show that Canadian art prices seem to be largely independent of American and European ones, and thus it is of interest to see how they would contribute to the diversification of non-Canadian collectors. To this end, we have estimated the capital asset pricing model (CAPM) for the Mei-Moses and Canadian indexes, using the Dow Jones as the proxy for market returns and the US Federal Funds Rate as the return series on a risk-free asset. The Canadian index was converted to US dollars using the exchange rate.

We have used the general stock index because under the CAPM, the "market" portfolio is the portfolio of all assets that exist in the world. The betas here then indicate how paintings contribute to an overall investment portfolio. We are basically interested in the contribution of Canadian paintings to the diversification of the financial portfolio of mainstream global asset markets as proxied by the Dow Jones. ${ }^{12}$

$<$ Table 12. approximately here >

The beta is very close to zero in this case, again supporting the results we have already obtained. ${ }^{13}$ The fact that we obtain a very small beta suggests that there is diversification potential with Canadian art that is greater than with US and European art,

\footnotetext{
${ }^{12}$ This is a different question than the one that was asked by Hodgson and Vorkink (2004). They use the Toronto Stock Exchange as the market proxy, to examine portfolio diversification capabilities of Canadian paintings in the case of Canadian investors, who are assumed to be mostly invested in Canadian stocks.

${ }^{13}$ The beta parameter in the CAPM model captures the sensitivity of the excess returns on a particular asset to the excess returns on the market portfolio.
} 
which may be why the average return of US and European art is higher. ${ }^{14}$ The fact that very few non-Canadian investors take advantage of this diversification opportunity suggests a particularity of the Canadians' tastes for art. The consumption dividends (or "psychic returns") of Canadians from collecting Canadian art are higher than that of nonCanadians.

It is of interest to see if the independent variation of Canadian art prices can be associated with movements in general economic variables. To this end, we have added Canadian GDP and Canadian stock returns to the mix. Our aim is to see how much extra explanatory power for the Canadian index (relative to the Mei-Moses one) is contained in Canadian stock prices and Canadian GDP. Figures 5 and 6 show how these variables move (in log real levels and real returns) compared to art prices.

Canadian stock and art prices move closely for the period 1973-1990. However, art prices are much more volatile than stock prices. Canadian art prices do seem to have participated to some extent in the global decline in art prices of the early 1990's. Prices recovered in the late 1990's, again in common with global art price movements, but lagged behind stock prices. Another interesting observation is that although art prices declined following both the 1982 and 1990-1992 recessions, they reacted only slightly to the stock price corrections following the dot.com bubble and losses in high tech stocks. This point needs to be further investigated. Real stock returns and real returns for art were highly volatile during the seventies and eighties. The volatility in art investment returns has increased in recent years. The volatility of art and equity returns has been much larger than that of real GDP growth.

\footnotetext{
${ }^{14} \mathrm{As}$ for the regression of the Canadian art excess returns on the US art excess returns (using the Federal Funds rate and the same nominal returns) we find similar results.
} 
$<$ Figure 5 approximately here >

$<$ Figure 6 approximately here >

Overall, although there is some connection between movements in Canadian art prices and the global art market, this connection is very weak. In the absence of a good theory of art price determination that could explain this phenomenon or suggest alternative explanatory covariates, we proceed to investigate the statistical explanatory power, beyond that present in international art prices, of aggregate indicators of wealth and income in Canada, as measured by stock prices and national income. Log levels and returns for Canadian GDP and the Toronto Stock Exchange are plotted in Figures 5 and 6. In addition, a variety of statistics have been computed to measure this marginal explanatory power of Canadian aggregates.

There is no cointegration in any combination of Canadian art prices with international art prices, Canadian GDP, or Canadian stocks. ${ }^{15}$ We have also tested Granger-causality of 1 to 6 lags of these three variables on Canadian art returns, and we have obtained an insignificant chi-square statistic at all lags, with the largest being 4.72 at one lag (3 degress of freedom). Therefore, we cannot reject the null hypothesis of no Granger causality. ${ }^{16}$ From these results we can conclude that there is no long-run relation between Canadian art prices and any of these variables, and that, furthermore, they are of limited use for the prediction of art returns (beyond what we found for the bivariate model reported above). Looking at the contemporaneous impact of these variables on art returns, we then ran a regression of Canadian art returns on a constant and the returns to these three variables (Mei-Moses Art price index, Canadian GDP and Canadian stock prices). The results are presented in Table 13.

\footnotetext{
${ }^{15}$ The results are available upon request.

${ }^{16}$ The related tests are not reported in detail in the paper. They are available upon request.
} 
$<$ Table 13 approximately here >

Real GDP growth and the increase in real returns of Canadian stocks have positive effects while global art price returns have a slightly negative effect on Canadian art prices. Only the coefficient of Canadian GDP turned out to be significant, whereas Canadian stocks and US art prices are not significant at any standard significance level. Therefore, we conclude that these three variables are only partly useful for explaining art prices. The only variable with an important effect on art price changes is real GDP, which has a strong contemporaneous effect, with a one percent change in real GDP inducing a change in art prices of 2.49 per cent.

Our results in this paper support the hypothesis that Canadian art prices move fairly independently of world prices. This does suggest independence of Canadian tastes, especially as Canadian art seems to yield lower real returns than the global market overall, suggesting that the consumption value of Canadian art is particularly high to Canadian collectors. This is consistent with the very limited interest of non-Canadian collectors in Canadian paintings.

The particularity of Canadian taste may be one of the factors in explaining price movements in the Canadian art market. The collecting styles of several famous Canadian art collectors and their tastes have had important effects in shaping the demand for Canadian art and hence the art supply in Canada. We may ask why it is that Canadian collectors are so attached to landscapes, by far the predominant genre in the Canadian art market. The answer will also be helpful to understand the lack of common price dynamics between Canadian and world art markets.

\section{Conclusion}


In the economics of art literature, there exist a number of studies which investigate whether the inclusion of art works into a financial portfolio can bring diversification benefits and the general conclusion is a qualified 'yes'. There are, however, only a handful of studies which investigate the price dynamics between different segments of the art market. In this context, we have used co-integration analysis and Granger-causality tests to investigate the inter-linkages between price dynamics in the Canadian and global paintings markets.

While Hodgson and Vorkink (2004) provide independent evidence (relative to the existing literature) on the general question of the properties of art as an investment, our findings indicate that the prices in the Canadian paintings auctions and the international art market prices are not co-integrated. This implies that, despite low shortterm fluctuations, price developments in the Canadian and international art markets do not move together in the long-run. Technically speaking, this does not mean that the returns necessarily diverge, but it only implies that the variance of the return differential between the two markets becomes infinitely large. However, the results from Grangercausality tests show that there may be some short-run feedback (or spillovers) between these markets.

We can confidently conclude from the results that deeper explanations are needed on the questions of the nature and origin of Canadian collectors' tastes in art. Canadian collectors' tastes for landscapes lie in nationalist sentiments deeply rooted in independent identity and nation building efforts throughout the early decades of $20^{\text {th }}$ century. They invest in their national identity when buying art. Abstract expressionist 
and contemporary art are considered as the symbols of universal tastes, and not sufficiently “Canadian”.

The idiosyncrasy of Canadian tastes may be an important factor in explaining art market dynamics specific to Canada. The collecting styles of several famous Canadian art collectors and their tastes have been important influences in shaping supply and demand for Canadian art. In this context, it may be of interest in future work to study the extent to which the lack of dynamic price dependence between global and local art markets may be attributable to home bias in the preferences of art collectors. There is a substantial body of work in the international trade literature stemming from Armington (1969) in which international price differentials for heterogeneous goods are explained by such home biases. ${ }^{17}$ The focus on home bias may help to clarify the demand and art price divergences between Canadian and world art markets. This is left for future work.

\section{ACKNOWLEDGEMENTS}

For their comments, our thanks to Patrick Richard and Erdal Atukeren and seminar participants at University of Ottawa, the 2009 CIREQ Colloquium on Computationally Intensive Econometrics, and the 2009 Annual Meetings of the ESAM, SCSE and CEA.

\section{BIBLIOGRAPHY}

\footnotetext{
${ }^{17}$ See Whalley and Xin (2009) for a recent discussion of this subject.
} 
Agnello, R.J. and R. K. Pierce (1996), "Financial Returns, Price Determinants, and Genre Effects in American Art Investment”, Journal of Cultural Economics, 20, pp. 359-383.

Armington, P.S. (1969), “A theory of demand for products distinguished by place of production”, International Monetary Fund Staff Papers, 16, 159-178.

Arvin, M. and M. Scigliano (2004), “Hedonic Prices in Art and Returns to Art Investment: Evidence from the Group of Seven at Auction”, Économie Appliquée, LVII(1), pp. 137- 162.

Atukeren, E. and A. Seckin, (2009) “An Analysis of The Price Dynamics Between The Turkish and The International Paintings Markets”, Applied Financial Economics, Vol.19, pp.1705-1714.

Bickel, P. (1982), “On Adaptive Estimation”, Annals of Statistics, Vol. 10, pp. 647-671. Burton, B. J. and J. P. Jacobsen (1999), “Measuring Returns on Investment in Collectibles”, Journal of Economic Perspectives, Vol. 13, No. 4, pp.193-212.

Campbell, H. 1970-1975. Canadian Art Auction Record 1969-1974, vols 1-6. Toronto: Canadian Antiques and Fine Arts; and Montreal: Bernard Amtmann.

Campbell, H. 1980. Canadian Art Auctions, Sales, and Prices, 1976-1978. Don Mills, Ont.: General. 
Dickey, D. and Fuller, W. 1979. Distribution of the estimators for autoregressive time series with a unit root. Journal of the American Statistical Association Vol.74, pp.42731.

Edwards, S. (2004), “On the Economics of Latin American Art: Creativity Patterns and Rates of Return”, Economia, Spring Issue, pp.1-35.

Ginsburgh, V. and P. Jeanfils, (1995), Long-term Comovements in International Markets for Paintings”, European Economic Review, Vol.39, pp.538-548.

Goetzmann, W. N. (1993), “Accounting For Taste: Art and the Financial Markets Over Three Centuries”, American Economic Review, Vol. 83, No. 5, pp.1370-1376.

Harper, J.R. 1977. Painting in Canada: A history (2nd ed.). Univ. of Toronto.

Higgs, H. and A. Worthington (2005), “Financial Returns and Price Determinants in the Australian Art Market 1973-2003”, Economic Record, Vol. 81, pp. 113-123.

Hodgson, D.J. (in press), “An Analysis of Pricing and Returns in the Market for French Canadian Paintings”, Applied Economics.

Hodgson, D. J. and K. P. Vorkink (2004), “Asset Pricing Theory and the Valuation of Canadian Paintings”, Canadian Journal of Economics, Vol. 37, No.3, pp.629-655. 
Mei, J. and M. Moses (2002), “Art as an Investment and the Underperformance of Masterpieces”, American Economic Review, Vol. 92, No. 5, pp.1656-1668.

Mok, H.M.K., Ko, V.M.K., Woo, S.S.M. and Kwok, K.Y.S. (1993), “Modern Chinese Paintings: An Investment Alternative”, Southern Economic Journal, Vol. 92, pp. 808816.

Phillips, P.C.B. and P. Perron (1988), “Testing for a Unit Root in Time Series Regression”, Biometrika, Vol. 75, pp.335-346.

Reid, D. 1973. A Concise History of Canadian Painting. Toronto: Oxford.

Reid, D. 1979. Our Own Country Canada. Ottawa: National Gallery of Canada.

Reid, D. 1988. A Concise History of Canadian Painting (2nd ed.). Toronto: Oxford.

Seckin, A. and E. Atukeren (2006), “Art and the Economy: A First Look at the Market for Paintings in Turkey”, Economics Bulletin, Vol. 26, No. 3, pp.1-13.

Sotheby’s. 1975. Canadian Art at Auction, 1968-1975. Toronto: Sotheby’s.

Sotheby's. 1980. Canadian Art at Auction, 1975-1980. Toronto: Sotheby’s.

Valsan, C. (2002), “Canadian versus American Art, What Pays Off and Why”, Journal of Cultural Economics, Vol. 26, pp.203-216. 
Westbridge, A.R. 1981-2008. Canadian Art Sales Index, 1977-2008. Vancouver: Westbridge.

Whalley, J. and Xin, X. (2009), “Home and Regional Biases and Border Effects in Armington Type models”, Economic Modelling, vol.26, pp.309-319.

Worthington, A. C. and H. Higgs (2003), “Art as an Investment: Short and Long-term Co-movements in Major Painting Markets”, Empirical Economics, Vol. 28, pp.649-668. 


\section{APPENDIX}

Fig. 1 - Log Mei-Moses Index (Solid) and Log Canadian Index (Broken)

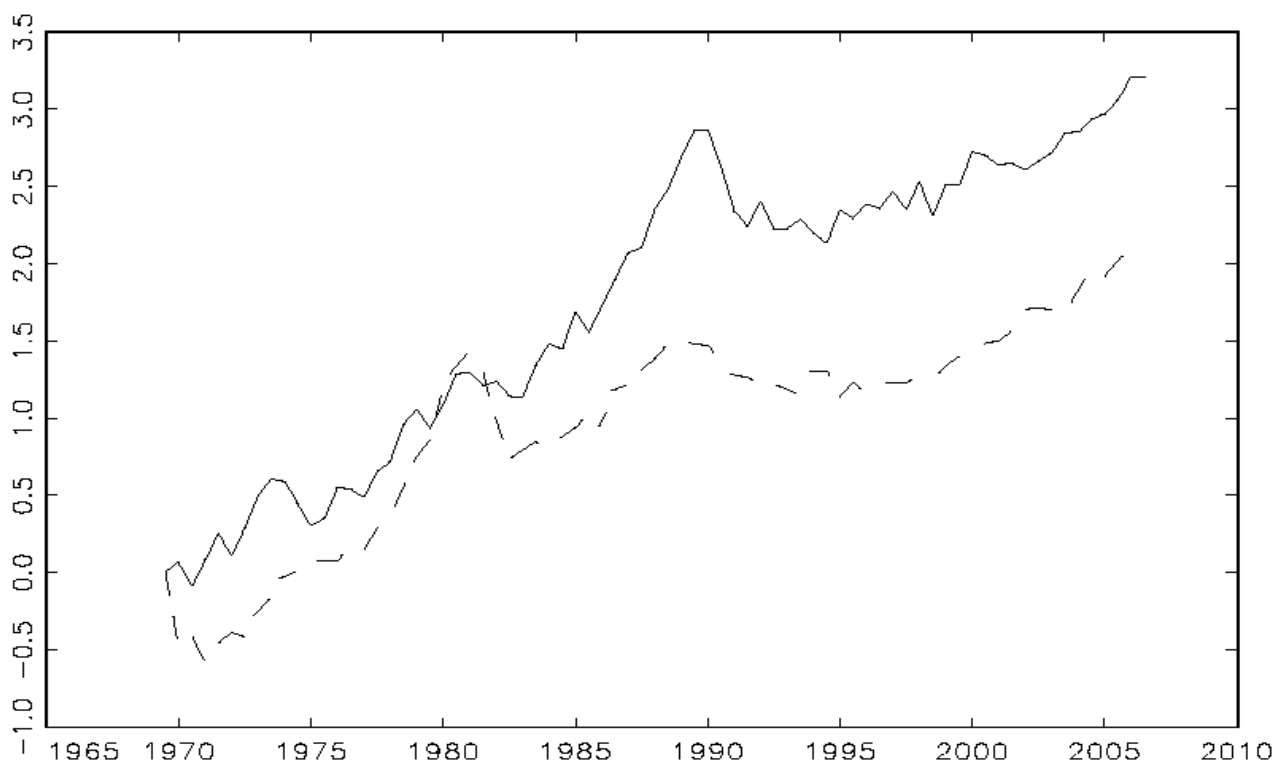

Fig. 2 - Returns: Mei-Moses Index and Canadian Index (Broken)

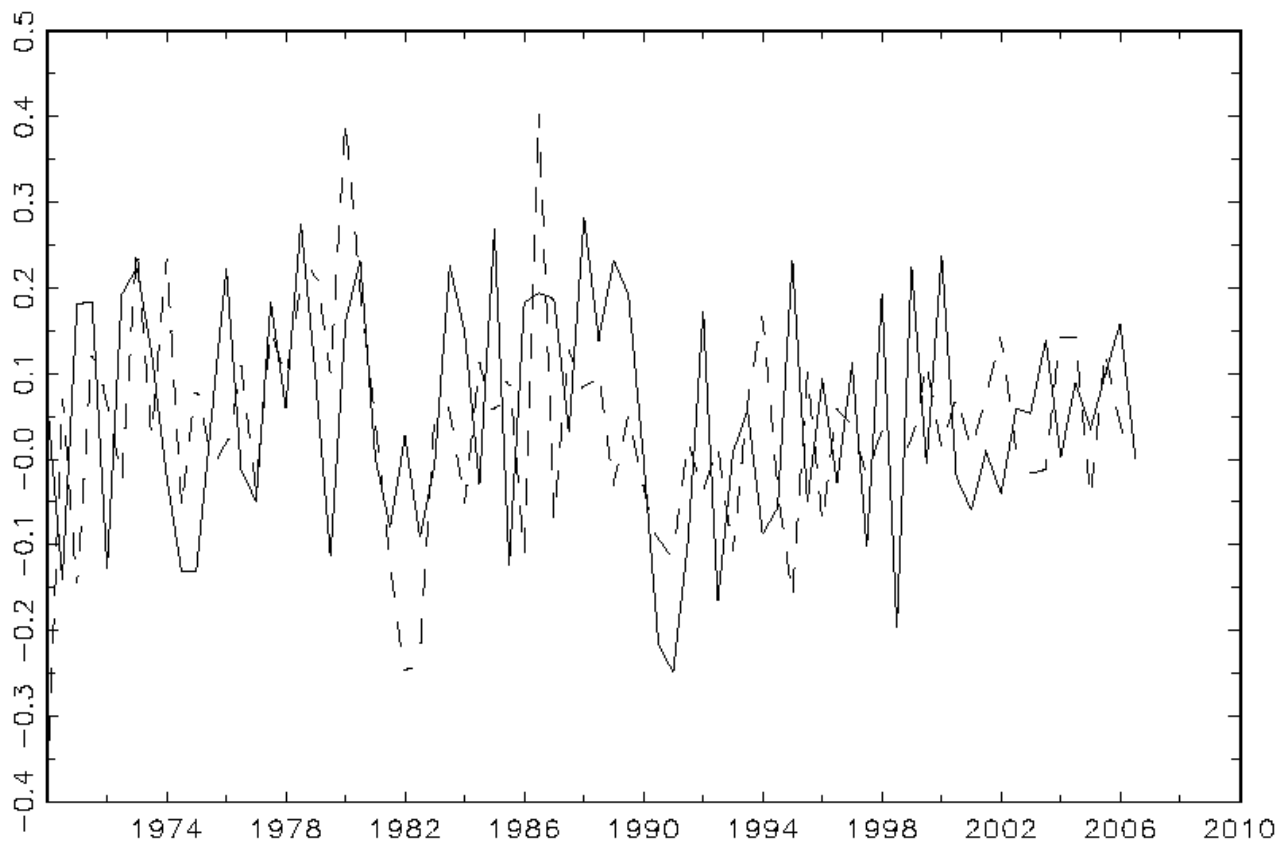


ig. 3 - Log Real Index (Same Currency): Mei-Moses and Canada (Broken)

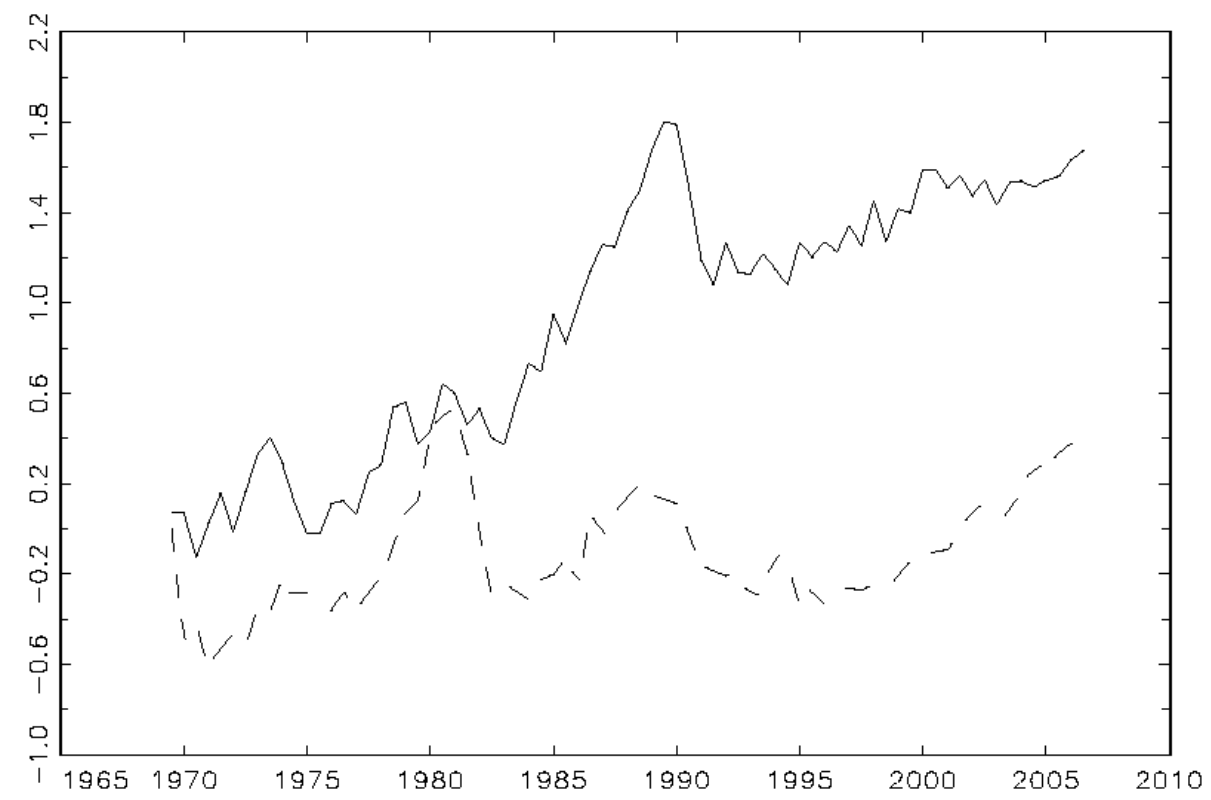

Fig. 4 - Real Returns (Same Currency): Mei-Moses and Canada (Broken)

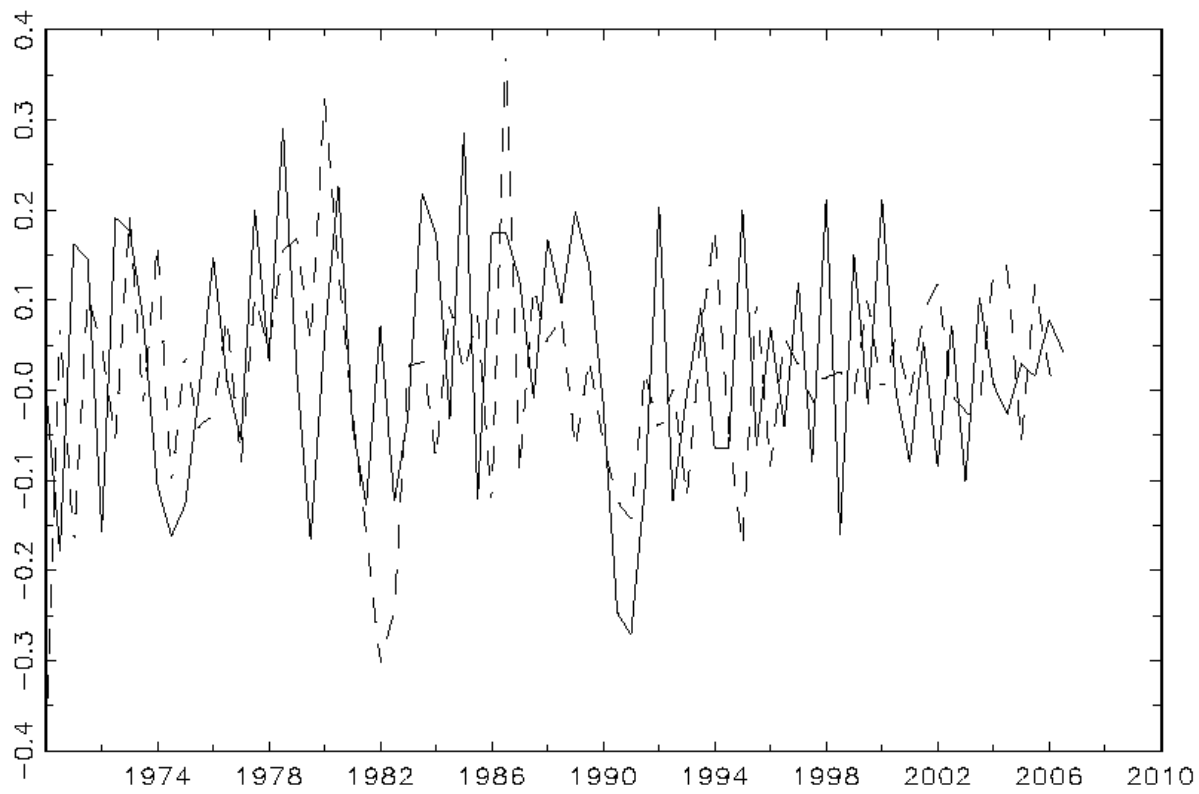


Fig. 5 - Log Real Canadian Art, GDP(Broken), and Stocks (Dots)

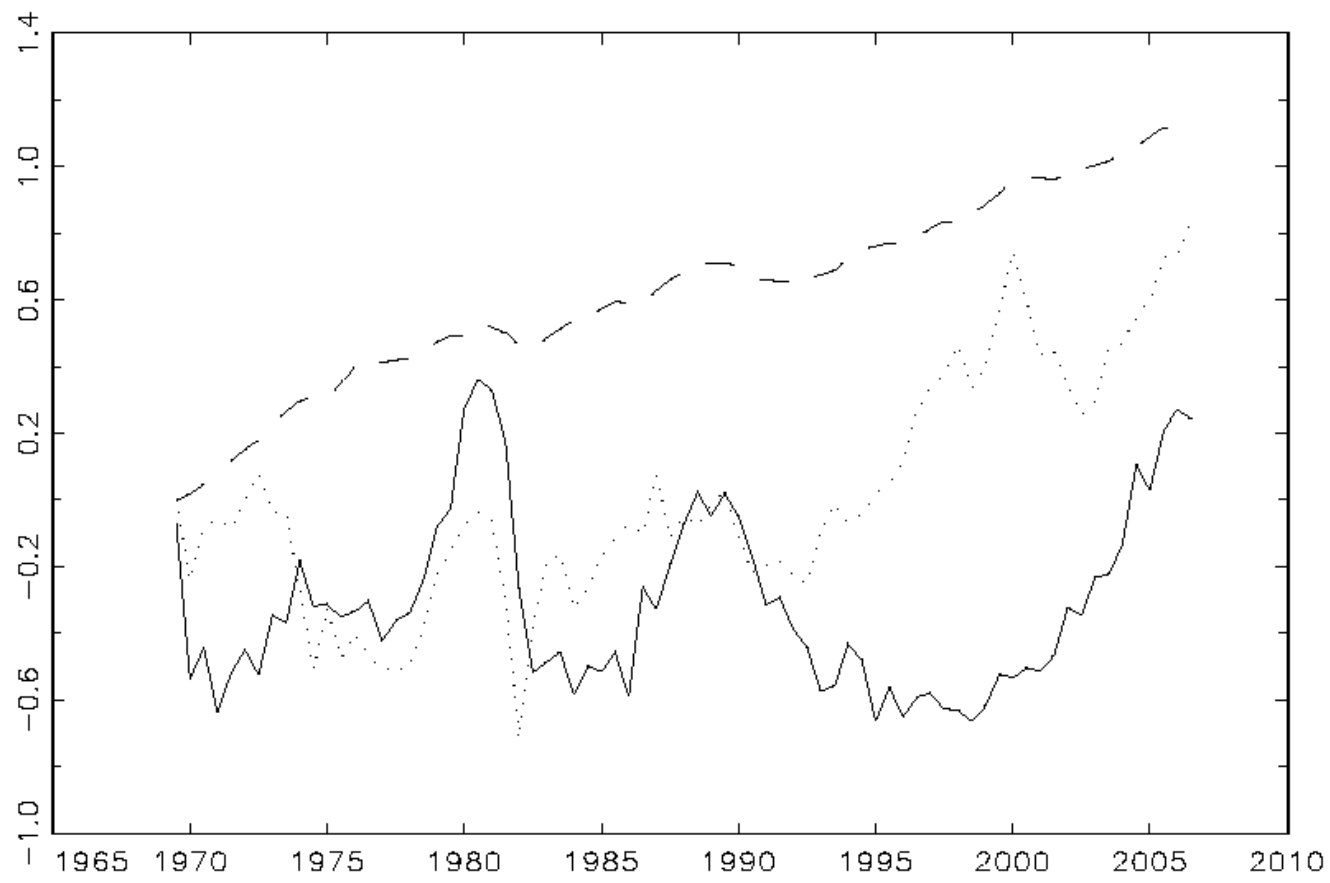

Fig. 6 - Real Returns: Canadian Art, GDP(Broken), and Stocks (Dots)

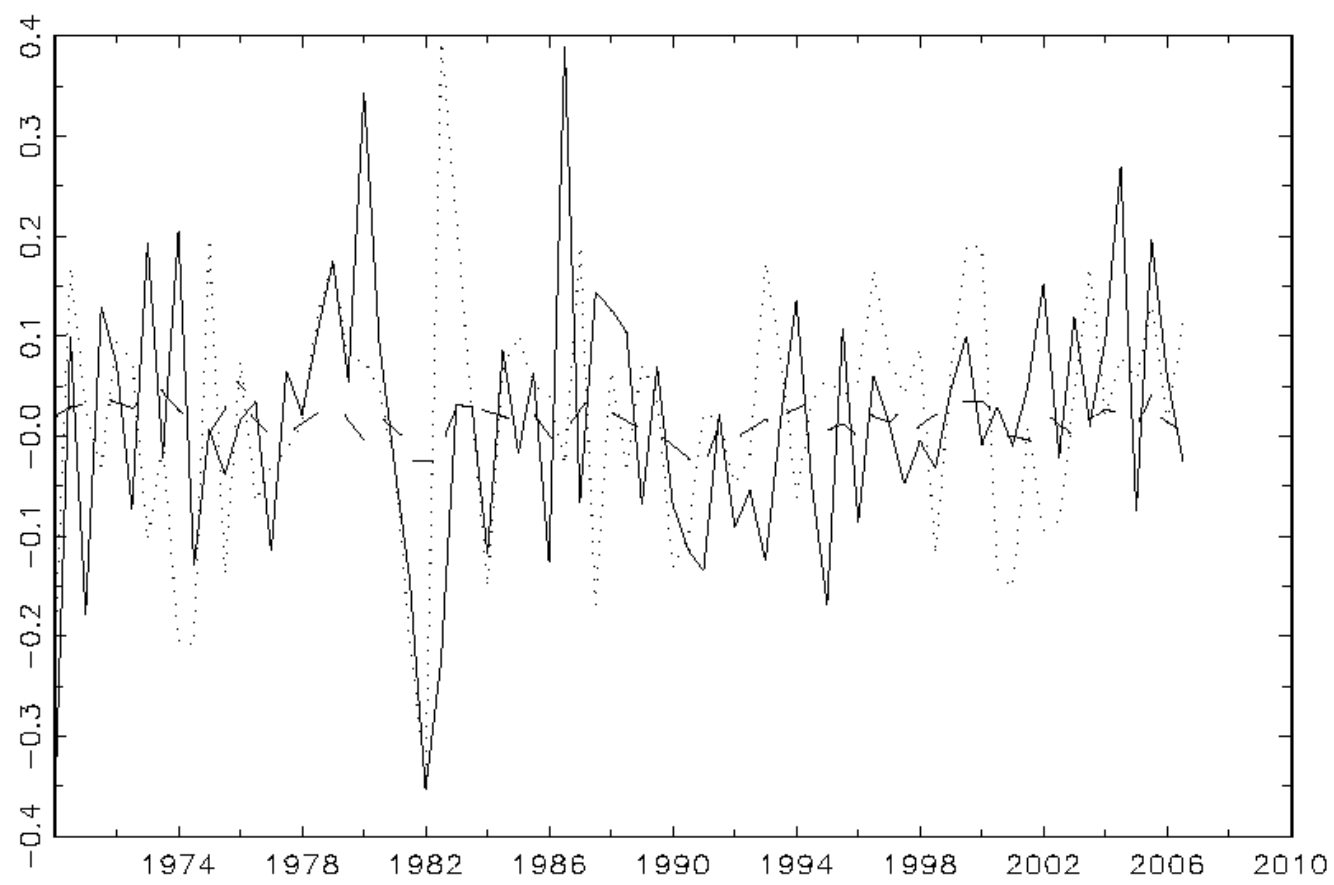


Table 1: Hedonic price index and returns, 1968-2008

\begin{tabular}{|c|c|c|c|c|c|c|c|c|c|}
\hline $\begin{array}{l}\text { Half- } \\
\text { year }\end{array}$ & Index & S.E. & $\begin{array}{l}\text { Return } \\
(\%)\end{array}$ & S.E. & $\begin{array}{l}\text { Half- } \\
\text { year }\end{array}$ & Index & S.E. & $\begin{array}{l}\text { Return } \\
\text { (\%) }\end{array}$ & S.E. \\
\hline $68: 2$ & 6.767 & .110 & 0 & 0 & $88: 2$ & 8.763 & .044 & 10.13 & 5.05 \\
\hline 69:1 & 7.070 & .091 & 35.40 & 18.52 & 89:1 & 8.730 & .043 & -3.26 & 4.43 \\
\hline 69:2 & 7.279 & .088 & 23.25 & 14.83 & $89: 2$ & 8.781 & .044 & 5.24 & 4.89 \\
\hline 70:1 & 6.791 & .049 & -38.60 & 5.72 & $90: 1$ & 8.749 & .044 & -3.19 & 4.58 \\
\hline 70:2 & 6.865 & .055 & 7.66 & 6.20 & $90: 2$ & 8.639 & .045 & -10.40 & 4.36 \\
\hline 71:1 & 6.698 & .056 & -15.42 & 5.32 & 91:1 & 8.521 & .052 & -11.16 & 5.00 \\
\hline 71:2 & 6.821 & .065 & 13.11 & 8.16 & 91:2 & 8.541 & .049 & 2.05 & 6.04 \\
\hline $72: 1$ & 6.887 & .057 & 6.82 & 7.83 & $92: 1$ & 8.502 & .050 & -3.80 & 5.54 \\
\hline $72: 2$ & 6.862 & .057 & -2.50 & 6.48 & $92: 2$ & 8.518 & .049 & 1.56 & 5.81 \\
\hline 73:1 & 7.083 & .063 & 24.82 & 8.92 & 93:1 & 8.398 & .052 & -11.25 & 5.25 \\
\hline 73:2 & 7.109 & .061 & 2.64 & 7.72 & $93: 2$ & 8.463 & .052 & 6.70 & 6.55 \\
\hline 74:1 & 7.325 & .060 & 24.01 & 9.09 & $94: 1$ & 8.621 & .051 & 17.07 & 7.04 \\
\hline 74:2 & 7.265 & .060 & -5.74 & 6.89 & $94: 2$ & 8.585 & .049 & -3.50 & 5.60 \\
\hline 75:1 & 7.353 & .081 & 9.12 & 10.22 & $95: 1$ & 8.410 & .048 & -16.08 & 4.71 \\
\hline 75:2 & 7.350 & .092 & -0.25 & 11.70 & $95: 2$ & 8.508 & .050 & 10.26 & 6.25 \\
\hline $76: 1$ & 7.355 & .061 & 0.48 & 10.45 & $96: 1$ & 8.430 & .049 & -7.50 & 5.18 \\
\hline $76: 2$ & 7.459 & .070 & 10.95 & 9.03 & $96: 2$ & 8.494 & .048 & 6.61 & 5.88 \\
\hline 77:1 & 7.423 & .063 & -3.50 & 8.09 & $97: 1$ & 8.530 & .049 & 3.74 & 5.74 \\
\hline 77:2 & 7.564 & .066 & 15.12 & 9.31 & $97: 2$ & 8.512 & .046 & -1.82 & 5.18 \\
\hline 78:1 & 7.655 & .059 & 9.55 & 8.54 & 98:1 & 8.545 & .048 & 3.32 & 5.40 \\
\hline 78:2 & 7.838 & .058 & 20.09 & 8.60 & $98: 2$ & 8.563 & .045 & 1.89 & 5.24 \\
\hline 79:1 & 8.045 & .061 & 22.93 & 9.00 & 99:1 & 8.576 & .049 & 1.30 & 5.21 \\
\hline 79:2 & 8.139 & .060 & 9.84 & 8.35 & 99:2 & 8.683 & .046 & 11.22 & 5.86 \\
\hline 80:1 & 8.472 & .061 & 39.63 & 10.60 & 00:1 & 8.696 & .047 & 1.29 & 5.22 \\
\hline 80:2 & 8.652 & .052 & 19.61 & 8.32 & $00: 2$ & 8.767 & .044 & 7.36 & 5.34 \\
\hline 81:1 & 8.695 & .051 & 4.49 & 6.37 & 01:1 & 8.779 & .044 & 1.21 & 4.59 \\
\hline 81:2 & 8.568 & .053 & -12.01 & 5.41 & 01:2 & 8.848 & .047 & 7.14 & 5.16 \\
\hline 82:1 & 8.267 & .053 & -25.97 & 4.66 & 02:1 & 8.986 & .044 & 14.82 & 5.59 \\
\hline $82: 2$ & 8.012 & .064 & -22.48 & 5.66 & $02: 2$ & 8.994 & .044 & 0.84 & 4.65 \\
\hline 83:1 & 8.065 & .060 & 5.38 & 8.27 & 03:1 & 8.978 & .042 & -1.65 & 4.35 \\
\hline 83:2 & 8.124 & .062 & 6.14 & 8.10 & 03:2 & 8.966 & .044 & -1.19 & 4.37 \\
\hline 84:1 & 8.068 & .059 & -5.51 & 7.15 & 04:1 & 9.109 & .046 & 15.45 & 5.50 \\
\hline $84: 2$ & 8.175 & .059 & 11.35 & 8.16 & 04:2 & 9.242 & .046 & 14.22 & 5.73 \\
\hline $85: 1$ & 8.220 & .052 & 4.57 & 7.05 & $05: 1$ & 9.196 & .043 & -4.49 & 4.62 \\
\hline 85:2 & 8.318 & .049 & 10.27 & 6.47 & $05: 2$ & 9.316 & .044 & 12.73 & 5.05 \\
\hline $86: 1$ & 8.200 & .048 & -11.09 & 4.88 & $06: 1$ & 9.351 & .045 & 3.56 & 4.80 \\
\hline $86: 2$ & 8.543 & .044 & 40.91 & 7.12 & $06: 2$ & 9.360 & .045 & 0.86 & 4.84 \\
\hline $87: 1$ & 8.471 & .044 & -6.97 & 4.34 & $07: 1$ & 9.512 & .044 & 16.47 & 5.39 \\
\hline 87:2 & 8.597 & .045 & 13.42 & 5.44 & $07: 2$ & 9.644 & .043 & 14.05 & 5.20 \\
\hline 88:1 & 8.667 & .043 & 7.28 & 5.06 & 08:1 & 9.630 & .044 & -1.38 & 4.62 \\
\hline
\end{tabular}


Table 2-- Top 25 Canadian Painters

\begin{tabular}{|c|c|c|c|c|c|}
\hline Rank & Artist & $\begin{array}{l}\text { Dummy } \\
\text { estimate }\end{array}$ & Std.Err. & $\begin{array}{l}\text { \% } \Delta . r e l . \\
\text { Jackson }\end{array}$ & Std. Err. \\
\hline 1 & Tom Thomson & 2.065 & 0.065 & 688.1 & 51.61 \\
\hline 2 & William Berczy & 1.587 & 0.499 & 388.86 & 243.94 \\
\hline 3 & Frank Carmichael & 1.312 & 0.078 & 271.31 & 29.09 \\
\hline 4 & Paul-Emile Borduas & 1.101 & 0.084 & 200.85 & 25.13 \\
\hline 5 & Lawren S Harris & 0.993 & 0.036 & 170.02 & 9.68 \\
\hline 6 & Cornelius Krieghoff & 0.952 & 0.037 & 159.03 & 9.69 \\
\hline 7 & Emily Carr & 0.928 & 0.053 & 152.94 & 13.32 \\
\hline 8 & J.W. Morrice & 0.871 & 0.05 & 139.01 & 11.86 \\
\hline 9 & Jean-Paul Riopelle & 0.811 & 0.051 & 125 & 11.59 \\
\hline 10 & David Milne & 0.776 & 0.061 & 117.45 & 13.2 \\
\hline 11 & Paul Kane & 0.759 & 0.237 & 113.59 & 50.56 \\
\hline 12 & James Duncan & 0.724 & 0.5 & 106.37 & 103.23 \\
\hline 13 & Fred Varley & 0.421 & 0.058 & 52.38 & 8.79 \\
\hline 14 & Helen McNicholl & 0.342 & 0.121 & 40.73 & 17.08 \\
\hline 15 & Alex Colville & 0.332 & 0.226 & 39.42 & 31.45 \\
\hline 16 & J-B Roy-Audy & 0.305 & 0.5 & 35.66 & 67.83 \\
\hline 17 & W.G.R. Hind & 0.183 & 0.5 & 20.04 & 60 \\
\hline 18 & J.E.H. Macdonald & 0.171 & 0.037 & 18.67 & 4.42 \\
\hline 19 & Clarence Gagnon & 0.073 & 0.044 & 7.52 & 4.76 \\
\hline 20 & A. Y. Jackson & - & - & 0 & 0 \\
\hline 21 & A.J. Casson & -0.002 & 0.032 & -0.22 & 3.17 \\
\hline 22 & Jean-Paul Lemieux & -0.022 & 0.053 & -2.16 & 5.18 \\
\hline 23 & Paul Peel & -0.044 & 0.072 & -4.29 & 6.85 \\
\hline 24 & Kathleen Morris & -0.059 & 0.072 & -5.7 & 6.84 \\
\hline 25 & Christopher Pratt & -0.093 & 0.289 & -8.85 & 26.32 \\
\hline
\end{tabular}


Table 3 - Individual artist dummy parameter estimates (A.Y. Jackson excluded) Each parameter measures effect of artist relative to Jackson

\begin{tabular}{|c|c|c|c|c|c|c|c|c|c|}
\hline Artist & Parameter & S.E. & $\begin{array}{l}\% \\
\text { Change } \\
\text { rel. to } \\
\text { Jackson }\end{array}$ & S.E. & Artist & Parameter & S.E. & $\begin{array}{l}\% \\
\text { Change } \\
\text { rel. to } \\
\text { Jackson }\end{array}$ & S.E. \\
\hline Carl Ahrens & -3.134 & .099 & -95.64 & 0.43 & $\begin{array}{l}\text { Illingworth } \\
\text { Kerr }\end{array}$ & -2.026 & .050 & -86.82 & 0.65 \\
\hline John Alfsen & -3.337 & .141 & -96.44 & 0.50 & Roy Kiyooka & -2.153 & .412 & -88.39 & 4.79 \\
\hline $\begin{array}{l}\text { Edmund } \\
\text { Alleyn }\end{array}$ & -2.498 & .099 & -91.78 & 0.81 & $\begin{array}{l}\text { Harold } \\
\text { Klunder }\end{array}$ & -2.189 & .411 & -88.80 & 4.61 \\
\hline $\begin{array}{l}\text { William } \\
\text { Armstrong }\end{array}$ & -2.895 & .214 & -94.47 & 1.18 & $\begin{array}{l}\text { Dorothy } \\
\text { Knowles }\end{array}$ & -2.269 & .088 & -89.66 & 0.91 \\
\hline $\begin{array}{l}\text { William E. } \\
\text { Atkinson }\end{array}$ & -2.888 & .073 & -94.43 & 0.40 & John Korner & -3.4147 & .160 & -96.82 & 0.51 \\
\hline $\begin{array}{l}\text { Marcel } \\
\text { Barbeau }\end{array}$ & -2.397 & .116 & -90.91 & 1.05 & $\begin{array}{l}\text { Cornelius } \\
\text { Krieghoff }\end{array}$ & 0.952 & .037 & 159.03 & 9.69 \\
\hline J.M. Barnsly & -2.113 & .083 & -87.91 & 1.00 & $\begin{array}{l}\text { William } \\
\text { Kurelek }\end{array}$ & -0.871 & .081 & -58.13 & 3.39 \\
\hline $\begin{array}{l}\text { Maxwell } \\
\text { Bates }\end{array}$ & -1.932 & .056 & -85.51 & 0.82 & Ludger Larose & -2.139 & .120 & -88.22 & 1.42 \\
\hline $\begin{array}{l}\text { William } \\
\text { Beatty }\end{array}$ & -1.411 & .039 & -75.62 & 0.94 & $\begin{array}{l}\text { Fernand } \\
\text { Leduc }\end{array}$ & -1.023 & .226 & -64.06 & 8.11 \\
\hline Henri Beau & -1.926 & .071 & -85.43 & 1.04 & Ozias Leduc & -0.556 & .104 & -42.66 & 5.95 \\
\hline $\begin{array}{l}\text { Leon } \\
\text { Bellefleur }\end{array}$ & -1.213 & .066 & -70.26 & 1.97 & Joseph Legare & -1.142 & .251 & -68.09 & 8.01 \\
\hline $\begin{array}{l}\text { F.M. Bell- } \\
\text { Smith }\end{array}$ & -1.492 & .045 & -77.51 & 1.02 & $\begin{array}{l}\text { Jean-Paul } \\
\text { Lemieux }\end{array}$ & -0.022 & .053 & -2.16 & 5.18 \\
\hline Louis Belzile & -3.365 & .162 & -96.55 & 0.56 & Rita Letendre & -2.074 & .088 & -87.44 & 1.11 \\
\hline $\begin{array}{l}\text { Aleksandre } \\
\text { Bercovitch }\end{array}$ & -3.250 & .133 & -96.12 & 0.52 & Ernst Lindner & -1.487 & .214 & -77.40 & 4.84 \\
\hline $\begin{array}{l}\text { William } \\
\text { Berczy }\end{array}$ & 1.587 & .499 & 388.86 & 243.94 & $\begin{array}{l}\text { Arthuer } \\
\text { Lismer }\end{array}$ & -0.349 & .035 & -29.43 & 2.44 \\
\hline $\begin{array}{l}\text { Suzanne } \\
\text { Bergeron }\end{array}$ & -3.356 & .216 & -96.51 & 0.75 & $\begin{array}{l}\text { Kenneth } \\
\text { Lochhead }\end{array}$ & -2.022 & .165 & -86.76 & 2.18 \\
\hline G.T. Berthon & -1.321 & .252 & -73.32 & 6.73 & $\begin{array}{l}\text { Mabel } \\
\text { Lockerby }\end{array}$ & -0.868 & .205 & -58.02 & 8.59 \\
\hline Andre Bieler & -1.840 & .075 & -84.12 & 1.19 & $\begin{array}{l}\text { Alexandra } \\
\text { Luke }\end{array}$ & -1.822 & .215 & -83.83 & 3.47 \\
\hline B.C. Binning & -0.666 & .147 & -48.64 & 7.57 & $\begin{array}{l}\text { Laura Muntz } \\
\text { Lyall }\end{array}$ & -1.772 & .086 & -83.00 & 1.45 \\
\hline $\begin{array}{l}\text { Ebenezer } \\
\text { Birrell }\end{array}$ & -2.870 & .705 & -94.33 & 4.00 & John Lyman & -1.197 & .070 & -69.79 & 2.13 \\
\hline $\begin{array}{l}\text { Ronald } \\
\text { Bloore }\end{array}$ & -1.924 & .200 & -85.40 & 2.92 & Frank Lynn & -0.478 & .709 & -38.02 & 43.94 \\
\hline Bruno Bobak & -2.547 & .055 & -92.16 & 0.43 & $\begin{array}{l}\text { J.E.H. } \\
\text { Macdonald }\end{array}$ & 0.171 & .037 & 18.67 & 4.42 \\
\hline David Bolduc & -2.587 & .190 & -92.47 & 1.43 & $\begin{array}{l}\text { Jock } \\
\text { Macdonald }\end{array}$ & -0.984 & .097 & -62.62 & 3.61 \\
\hline $\begin{array}{l}\text { Paul-Emile } \\
\text { Borduas }\end{array}$ & 1.101 & .084 & 200.85 & 25.13 & $\begin{array}{l}\text { Hugh } \\
\text { Mackenzie }\end{array}$ & -1.351 & .355 & -74.11 & 9.19 \\
\hline $\begin{array}{l}\text { Joseph } \\
\text { Bouchette }\end{array}$ & -3.867 & .410 & -97.91 & 0.86 & $\begin{array}{l}\text { Pegi Nichol } \\
\text { MacLeod }\end{array}$ & -1.984 & .082 & -86.25 & 1.13 \\
\hline Napoleon & -1.953 & .354 & -85.82 & 5.03 & Helen & 0.342 & .121 & 40.73 & 17.08 \\
\hline
\end{tabular}




\begin{tabular}{|c|c|c|c|c|c|c|c|c|c|}
\hline \multicolumn{5}{|l|}{ Bourassa } & \multicolumn{5}{|l|}{ McNicholl } \\
\hline John Boyle & -3.772 & .500 & -97.70 & 1.15 & Mabel May & -1.687 & .064 & -81.49 & 1.18 \\
\hline Fritz & -1.420 & .099 & -75.84 & 2.40 & Ron Martin & -2.296 & .239 & -89.93 & 2.41 \\
\hline $\begin{array}{l}\text { Brandtner } \\
\text { Claude } \\
\text { Breeze }\end{array}$ & -3.369 & .272 & -96.56 & 0.94 & T.M. Martin & -2.532 & .045 & -92.05 & 0.36 \\
\hline Fred Brigden & -2.299 & .061 & -89.97 & 0.61 & Henri Masson & -1.629 & .032 & -80.39 & 0.63 \\
\hline Miller Brittain & -1.023 & .254 & -64.05 & 9.12 & $\begin{array}{l}\text { Marmaduke } \\
\text { Matthews }\end{array}$ & -2.553 & .140 & -92.22 & 1.09 \\
\hline $\begin{array}{l}\text { Bertram } \\
\text { Brooker }\end{array}$ & -1.509 & .100 & -77.89 & 2.21 & $\begin{array}{l}\text { Clark } \\
\text { McDougall }\end{array}$ & -2.264 & .178 & -89.61 & 1.85 \\
\hline D.P. Brown & -2.888 & .705 & -94.43 & 3.92 & Jean Mcewen & -1.556 & .075 & -78.90 & 1.57 \\
\hline $\begin{array}{l}\text { Archibald } \\
\text { Browne }\end{array}$ & -3.205 & .062 & -95.88 & 0.25 & $\begin{array}{l}\text { Yvonne } \\
\text { Mckague }\end{array}$ & -2.012 & .068 & -86.63 & 0.90 \\
\hline $\begin{array}{l}\text { Franklin } \\
\text { Brownell }\end{array}$ & -1.681 & .064 & -81.37 & 1.20 & Arthur Mckay & -2.435 & .355 & -91.24 & 3.11 \\
\hline W.B. Bruce & -2.025 & .143 & -86.81 & 1.88 & $\begin{array}{l}\text { Isabel } \\
\text { Mclaughlin }\end{array}$ & -2.365 & .143 & -90.61 & 1.34 \\
\hline $\begin{array}{l}\text { William } \\
\text { Brymner }\end{array}$ & -1.473 & .062 & -77.08 & 1.41 & Ray Mead & -2.205 & .192 & -88.98 & 2.11 \\
\hline $\begin{array}{l}\text { Dennis } \\
\text { Burton }\end{array}$ & -2.946 & .169 & -94.75 & 0.89 & John Meredith & -2.087 & .162 & -87.60 & 2.00 \\
\hline Jack Bush & -1.036 & .087 & -64.53 & 3.07 & David Milne & 0.776 & .061 & 117.45 & 13.20 \\
\hline Oscar Cahen & -1.324 & .411 & -73.40 & 10.93 & $\begin{array}{l}\text { Guido } \\
\text { Molinari }\end{array}$ & -1.074 & .172 & -65.84 & 5.87 \\
\hline $\begin{array}{l}\text { Alex } \\
\text { Cameron }\end{array}$ & -4.460 & .706 & -98.84 & 0.82 & Guy Monpetit & -2.819 & .357 & -94.03 & 2.13 \\
\hline $\begin{array}{l}\text { Frank } \\
\text { Carmichael }\end{array}$ & 1.312 & .078 & 271.31 & 29.09 & Ron Moppett & -3.050 & .710 & -95.26 & 3.36 \\
\hline Emily Carr & .928 & .053 & 152.94 & 13.42 & J.W. Morrice & 0.871 & .050 & 139.01 & 11.86 \\
\hline A.J. Casson & -.002 & .032 & -0.22 & 3.17 & $\begin{array}{l}\text { Edmund } \\
\text { Morris }\end{array}$ & -2.305 & .106 & -90.02 & 1.06 \\
\hline $\begin{array}{l}\text { Jack } \\
\text { Chambers }\end{array}$ & -1.418 & .290 & -75.78 & 7.02 & $\begin{array}{l}\text { Kathleen } \\
\text { Morris }\end{array}$ & -0.059 & .072 & -5.70 & 6.84 \\
\hline W.H. Clapp & -1.474 & .091 & -77.10 & 2.09 & $\begin{array}{l}\text { Michael } \\
\text { Morris }\end{array}$ & -3.484 & .291 & -96.93 & 0.89 \\
\hline $\begin{array}{l}\text { Paraskeva } \\
\text { Clark }\end{array}$ & -2.259 & .111 & -89.56 & 1.16 & $\begin{array}{l}\text { Norval } \\
\text { Morriseau }\end{array}$ & -2.345 & .064 & -90.41 & 0.62 \\
\hline F.S. Coburn & -0.736 & .040 & -52.07 & 1.91 & $\begin{array}{l}\text { Douglas } \\
\text { Morton }\end{array}$ & -2.962 & .709 & -94.83 & 3.67 \\
\hline Alex Colville & 0.332 & .226 & 39.42 & 31.45 & $\begin{array}{l}\text { Jean-Paul } \\
\text { Mousseau }\end{array}$ & -2.261 & .197 & -89.57 & 2.06 \\
\hline $\begin{array}{l}\text { Charles } \\
\text { Comfort }\end{array}$ & -1.580 & .059 & -79.41 & 1.21 & $\begin{array}{l}\text { Louis } \\
\text { Muhlstock }\end{array}$ & -2.818 & .093 & -94.03 & 0.56 \\
\hline Emily Coonan & -2.506 & .173 & -91.84 & 1.41 & $\begin{array}{l}\text { Kathleen } \\
\text { Munn }\end{array}$ & -4.144 & .707 & -98.41 & 1.12 \\
\hline $\begin{array}{l}\text { Stanley } \\
\text { Cosgrove }\end{array}$ & -1.177 & .032 & -69.17 & 0.98 & $\begin{array}{l}\text { Kazuo } \\
\text { Nakamura }\end{array}$ & -1.661 & .103 & -81.00 & 1.95 \\
\hline $\begin{array}{l}\text { Graham } \\
\text { Coughtry }\end{array}$ & -2.433 & .207 & -91.22 & 1.82 & $\begin{array}{l}\text { H. Ivan } \\
\text { Neilson }\end{array}$ & -3.687 & .354 & -97.50 & 0.89 \\
\hline $\begin{array}{l}\text { William } \\
\text { Cresswell }\end{array}$ & -2.364 & .137 & -90.59 & 1.29 & $\begin{array}{l}\text { Ernst } \\
\text { Neumann }\end{array}$ & -2.945 & .111 & -94.74 & 0.59 \\
\hline $\begin{array}{l}\text { William } \\
\text { Cruikshank }\end{array}$ & -2.084 & .236 & -87.56 & 2.94 & $\begin{array}{l}\text { Lilias T. } \\
\text { Newton }\end{array}$ & -1.986 & .191 & -86.28 & 2.62 \\
\hline $\begin{array}{l}\text { Maurice } \\
\text { Cullen }\end{array}$ & -0.097 & .045 & -9.21 & 4.11 & $\begin{array}{l}\text { Marion } \\
\text { Nicholl }\end{array}$ & -2.045 & .179 & -87.06 & 2.32 \\
\hline Jean Dallaire & -0.370 & .084 & -30.91 & 5.83 & Jack Nichols & -3.316 & .355 & -96.37 & 1.29 \\
\hline Ken Danby & -3.897 & .500 & -97.97 & 1.01 & John O’Brien & -1.612 & .407 & -80.05 & 8.13 \\
\hline
\end{tabular}




\begin{tabular}{|c|c|c|c|c|c|c|c|c|c|}
\hline $\begin{array}{l}\text { Georges } \\
\text { Delfosse }\end{array}$ & -2.295 & .062 & -89.93 & 0.63 & $\begin{array}{l}\text { Lucius } \\
\text { O’Brien }\end{array}$ & -1.451 & .131 & -76.55 & 3.06 \\
\hline $\begin{array}{l}\text { Louis de } \\
\text { Niverville }\end{array}$ & -2.746 & .225 & -93.58 & 1.44 & Daphne Odjig & -2.129 & .177 & -88.11 & 2.10 \\
\hline $\begin{array}{l}\text { Rodolphe de } \\
\text { Repentigny }\end{array}$ & -0.585 & .252 & -44.31 & 14.05 & Will Ogilvie & -2.895 & .132 & -94.47 & 0.73 \\
\hline $\begin{array}{l}\text { Jacques de } \\
\text { Tannancour }\end{array}$ & -1.362 & .093 & -74.38 & 2.38 & Toni Onley & -2.528 & .079 & -92.01 & 0.63 \\
\hline $\begin{array}{l}\text { Joseph } \\
\text { Drapell }\end{array}$ & -3.421 & .290 & -96.73 & 0.95 & Paul Peel & -0.044 & .072 & -4.29 & 6.85 \\
\hline $\begin{array}{l}\text { Rodolphe } \\
\text { Duguay }\end{array}$ & -2.173 & .085 & -88.62 & 0.97 & Alfred Pellan & -0.418 & .080 & -34.20 & 5.30 \\
\hline $\begin{array}{l}\text { Louis } \\
\text { Dulongpre }\end{array}$ & -3.374 & .706 & -96.58 & 2.42 & $\begin{array}{l}\text { Sophie } \\
\text { Pemberton }\end{array}$ & -2.425 & .207 & -91.15 & 1.83 \\
\hline $\begin{array}{l}\text { Albert } \\
\text { Dumouchel }\end{array}$ & -2.423 & .169 & -91.13 & 1.49 & $\begin{array}{l}\text { William } \\
\text { Perehudoff }\end{array}$ & -2.581 & .137 & -92.43 & 1.04 \\
\hline James Duncan & 0.724 & .500 & 106.37 & 103.23 & Henri Perré & -2.494 & .173 & -91.74 & 1.43 \\
\hline Wyatt Eaton & -1.903 & .408 & -85.09 & 6.09 & $\begin{array}{l}\text { Christiane } \\
\text { Pflug }\end{array}$ & -1.810 & .705 & -83.64 & 11.54 \\
\hline Allan Edson & -2.010 & .076 & -86.60 & 1.02 & W.J. Phillips & -2.144 & .408 & -88.28 & 4.78 \\
\hline Ric Evans & -2.854 & .706 & -94.24 & 4.07 & Robert Pilot & -0.465 & .032 & -37.21 & 2.00 \\
\hline $\begin{array}{l}\text { Patterson } \\
\text { Ewen }\end{array}$ & -1.124 & .161 & -67.49 & 5.24 & $\begin{array}{l}\text { A.S. } \\
\text { Plamondon }\end{array}$ & -1.800 & 199 & -83.47 & 3.28 \\
\hline Ivan Eyre & -1.090 & .167 & -66.37 & 5.61 & $\begin{array}{l}\text { Christopher } \\
\text { Pratt }\end{array}$ & -0.093 & .289 & -8.85 & 26.32 \\
\hline $\begin{array}{l}\text { A.S. } \\
\text { Falardeau }\end{array}$ & -2.411 & .201 & -91.02 & 1.81 & Mary Pratt & -0.9249 & .186 & -61.29 & 7.20 \\
\hline $\begin{array}{l}\text { Marcelle } \\
\text { Ferron }\end{array}$ & -1.491 & .081 & -77.49 & 1.83 & $\begin{array}{l}\text { William } \\
\text { Raphael }\end{array}$ & -1.622 & .076 & -80.24 & 1.49 \\
\hline Robert Field & -0.938 & .705 & -60.84 & 27.62 & Carl Ray & -4.081 & .323 & -98.31 & 0.55 \\
\hline Brian Fisher & -4.292 & .409 & -98.63 & 0.56 & $\begin{array}{l}\text { Gordon } \\
\text { Rayner }\end{array}$ & -3.064 & .290 & -95.33 & 1.35 \\
\hline $\begin{array}{l}\text { Lemoine } \\
\text { Fitzgerald }\end{array}$ & -0.602 & .077 & -45.24 & 4.24 & George Reid & -2.210 & .069 & -89.03 & 0.75 \\
\hline $\begin{array}{l}\text { John C. } \\
\text { Forbes }\end{array}$ & -2.850 & .074 & -94.21 & 0.43 & $\begin{array}{l}\text { Jean-Paul } \\
\text { Riopelle }\end{array}$ & 0.811 & .051 & 125.00 & 11.59 \\
\hline $\begin{array}{l}\text { Tom } \\
\text { Forrestall }\end{array}$ & -2.036 & .182 & -86.95 & 2.37 & $\begin{array}{l}\text { Milly } \\
\text { Ristvedt- } \\
\text { Handerek }\end{array}$ & -4.369 & .709 & -98.73 & 0.90 \\
\hline J.W.L. Forster & -3.049 & .090 & -95.26 & 0.43 & $\begin{array}{l}\text { Goodridge } \\
\text { Roberts }\end{array}$ & -0.941 & .033 & -60.96 & 1.28 \\
\hline $\begin{array}{l}\text { Michael } \\
\text { Forster }\end{array}$ & -2.716 & .154 & -93.39 & 1.02 & $\begin{array}{l}\text { H. Tomtu } \\
\text { Roberts }\end{array}$ & -2.782 & .271 & -93.81 & 1.68 \\
\hline M-A Fortin & -0.387 & .037 & -32.08 & 2.55 & $\begin{array}{l}\text { Sarah } \\
\text { Robertson }\end{array}$ & -1.538 & .103 & -78.51 & 2.21 \\
\hline Paul Fournier & -2.905 & .206 & -94.53 & 1.13 & $\begin{array}{l}\text { Albert } \\
\text { Robinson }\end{array}$ & -0.202 & .047 & -18.26 & 3.87 \\
\hline Daniel Fowler & -1.880 & .708 & -84.75 & 10.80 & Otto Rogers & -2.778 & .181 & -93.78 & 1.13 \\
\hline $\begin{array}{l}\text { Joseph } \\
\text { Franchere }\end{array}$ & -2.012 & .062 & -86.63 & 0.83 & $\begin{array}{l}\text { William } \\
\text { Ronald }\end{array}$ & -2.501 & .083 & -91.80 & 0.68 \\
\hline John A Fraser & -1.770 & .214 & -82.96 & 3.64 & $\begin{array}{l}\text { Harry } \\
\text { Rosenberg }\end{array}$ & -1.816 & .499 & -83.73 & 8.12 \\
\hline $\begin{array}{l}\text { Louise } \\
\text { Gadbois }\end{array}$ & -3.513 & .072 & -97.02 & 0.21 & J-B Roy-Audy & 0.305 & .500 & 35.66 & 67.83 \\
\hline Robert Gagen & -2.166 & .168 & -88.53 & 1.92 & $\begin{array}{l}\text { Ludger } \\
\text { Ruelland }\end{array}$ & -3.870 & .269 & -97.91 & 0.56 \\
\hline $\begin{array}{l}\text { Charles } \\
\text { Gagnon }\end{array}$ & -0.710 & .499 & -50.86 & 24.54 & John Russell & -2.471 & .095 & -91.55 & 0.80 \\
\hline
\end{tabular}




\begin{tabular}{|c|c|c|c|c|c|c|c|c|c|}
\hline $\begin{array}{l}\text { Clarence } \\
\text { Gagnon }\end{array}$ & 0.073 & .044 & 7.52 & 4.76 & $\begin{array}{l}\text { Joseph St- } \\
\text { Charles }\end{array}$ & -2.661 & .106 & -93.01 & 0.74 \\
\hline Erik Gamble & -3.897 & .709 & -97.97 & 1.44 & $\begin{array}{l}\text { Henry } \\
\text { Sandham }\end{array}$ & -2.145 & .097 & -88.29 & 1.14 \\
\hline Yves Gaucher & -1.528 & .254 & -78.31 & 5.50 & Allen Sapp & -2.390 & .057 & -90.84 & 0.52 \\
\hline $\begin{array}{l}\text { Pierre } \\
\text { Gauvreau }\end{array}$ & -1.022 & .170 & -64.01 & 6.13 & Anne Savage & -1.129 & .070 & -67.67 & 2.26 \\
\hline $\begin{array}{l}\text { Alexandre } \\
\text { Giffard }\end{array}$ & -1.222 & .408 & -70.55 & 12.00 & $\begin{array}{l}\text { William } \\
\text { Sawyer }\end{array}$ & -2.810 & .179 & -93.98 & 1.08 \\
\hline Charles Gill & -2.979 & .152 & -94.92 & 0.77 & Rolph Scarlett & -1.770 & .706 & -82.97 & 12.02 \\
\hline Ted Godwin & -2.603 & .109 & -92.59 & 0.81 & Carl Schaefer & -1.041 & .116 & -64.70 & 4.10 \\
\hline Jean Goguen & -1.658 & .500 & -80.96 & 9.52 & Charles Scott & -2.704 & .129 & -93.30 & 0.86 \\
\hline Eric Goldberg & -2.962 & .081 & -94.83 & 0.42 & Gerald Scott & -3.831 & .270 & -97.83 & 0.58 \\
\hline $\begin{array}{l}\text { Hortense } \\
\text { Gordon }\end{array}$ & -2.775 & .109 & -93.77 & 0.68 & Marian Scott & -2.877 & .130 & -94.37 & 0.73 \\
\hline $\begin{array}{l}\text { Richard } \\
\text { Gorman }\end{array}$ & -2.452 & .158 & -91.39 & 1.36 & Julian Seavey & -3.075 & .214 & -95.38 & 0.99 \\
\hline Kate Graham & -3.102 & .318 & -95.51 & 1.43 & Jack Shadbolt & -1.568 & .069 & -79.14 & 1.44 \\
\hline John Greer & -1.728 & .502 & -82.24 & 8.92 & Gordon Smith & -2.345 & .072 & -90.41 & 0.69 \\
\hline John Hall & -2.964 & .251 & -94.84 & 1.29 & Jori Smith & -2.600 & .078 & -92.57 & 0.58 \\
\hline Joice Hall & -3.573 & .409 & -97.19 & 1.15 & Michael Snow & -1.153 & .318 & -68.44 & 10.02 \\
\hline Jay Hambidge & -2.863 & .706 & -94.29 & 4.03 & $\begin{array}{l}\text { Daniel } \\
\text { Solomon }\end{array}$ & -2.702 & .361 & -93.29 & 2.42 \\
\hline $\begin{array}{l}\text { Theophile } \\
\text { Hamel }\end{array}$ & -1.196 & .199 & -69.77 & 6.02 & $\begin{array}{l}\text { Martin } \\
\text { Somerville }\end{array}$ & -1.119 & .408 & -67.33 & 13.32 \\
\hline $\begin{array}{l}\text { John } \\
\text { Hammond }\end{array}$ & -1.851 & .040 & -84.30 & 0.63 & Bruce St Clair & -2.908 & .501 & -94.54 & 2.73 \\
\hline $\begin{array}{l}\text { Lawren S } \\
\text { Harris }\end{array}$ & 0.993 & .036 & 170.02 & 9.68 & $\begin{array}{l}\text { Lionel } \\
\text { Stephenson }\end{array}$ & -2.407 & .075 & -90.99 & 0.68 \\
\hline $\begin{array}{l}\text { Lawren P } \\
\text { Harris }\end{array}$ & -2.508 & .268 & -91.86 & 2.18 & $\begin{array}{l}\text { William } \\
\text { Stevenson }\end{array}$ & -2.545 & .070 & -92.15 & 0.55 \\
\hline Robert Harris & -1.687 & .059 & -81.50 & 1.09 & $\begin{array}{l}\text { Francoise } \\
\text { Sullivan }\end{array}$ & -3.444 & .705 & -96.80 & 2.25 \\
\hline Doug Haynes & -3.650 & .217 & -97.40 & 0.56 & Philip Surrey & -1.581 & .061 & -79.43 & 1.25 \\
\hline Adrien Hebert & -2.094 & .070 & -87.68 & 0.86 & $\begin{array}{l}\text { M-A Suzor- } \\
\text { Cote }\end{array}$ & -0.414 & .045 & -33.89 & 2.95 \\
\hline $\begin{array}{l}\text { Robert } \\
\text { Hedrick }\end{array}$ & -3.542 & .225 & -97.11 & 0.65 & Takao Tanabe & -2.522 & .106 & -91.97 & 0.85 \\
\hline George Heriot & -2.865 & .500 & -94.30 & 2.85 & Tony Tascona & -3.450 & .410 & -96.83 & 1.30 \\
\hline $\begin{array}{l}\text { Prudence } \\
\text { Heward }\end{array}$ & -1.586 & .096 & -79.53 & 1.97 & $\begin{array}{l}\text { Tom } \\
\text { Thomson }\end{array}$ & 2.065 & .065 & 688.31 & 51.61 \\
\hline $\begin{array}{l}\text { Randolph } \\
\text { Hewton }\end{array}$ & -1.482 & .062 & -77.28 & 1.42 & Robert Todd & -0.150 & .354 & -13.94 & 30.42 \\
\hline W.G.R. Hind & 0.183 & .500 & 20.04 & 60.00 & $\begin{array}{l}\text { Fernand } \\
\text { Toupin }\end{array}$ & -2.777 & .098 & -93.78 & 0.61 \\
\hline Tom Hodgson & -2.480 & .179 & -91.63 & 1.50 & $\begin{array}{l}\text { Claude } \\
\text { Tousignant }\end{array}$ & -2.067 & .240 & -87.35 & 3.04 \\
\hline $\begin{array}{l}\text { A.W. } \\
\text { Holdstock }\end{array}$ & -1.381 & .214 & -74.88 & 5.37 & Harold Town & -2.011 & .081 & -86.62 & 1.08 \\
\hline $\begin{array}{l}\text { Edwin } \\
\text { Holgate }\end{array}$ & -0.103 & .062 & -9.86 & 5.56 & Tony Urquart & -2.401 & .190 & -90.93 & 1.72 \\
\hline $\begin{array}{l}\text { Robert } \\
\text { Holmes }\end{array}$ & -4.454 & .706 & -98.84 & 0.82 & Fred Varley & 0.421 & .058 & 52.38 & 8.79 \\
\hline $\begin{array}{l}\text { William R. } \\
\text { Hope }\end{array}$ & -3.853 & .267 & -97.88 & 0.57 & $\begin{array}{l}\text { Robert } \\
\text { Varvarande }\end{array}$ & -3.973 & .317 & -98.12 & 0.60 \\
\hline $\begin{array}{l}\text { Frances } \\
\text { Hopkins }\end{array}$ & -3.179 & .705 & -95.84 & 2.93 & $\begin{array}{l}\text { Frederick } \\
\text { Verner }\end{array}$ & -0.692 & .070 & -49.94 & 3.49 \\
\hline E.J. Hughes & -0.095 & .072 & -9.05 & 6.50 & Zacharie & -4.359 & .705 & -98.72 & 0.90 \\
\hline
\end{tabular}




\begin{tabular}{|c|c|c|c|c|c|c|c|c|c|}
\hline Jack & -2.051 & .089 & -87.13 & 1.14 & $\begin{array}{l}\text { Vincent } \\
\text { Adolph Vogt }\end{array}$ & -1.911 & .198 & -85.21 & 2.93 \\
\hline Humphrey & & & & & & & & & \\
\hline Charles Huot & -1.955 & .097 & -85.84 & 1.38 & $\begin{array}{l}\text { Horatio } \\
\text { Walker }\end{array}$ & -1.197 & .072 & -69.80 & 2.17 \\
\hline $\begin{array}{l}\text { Jacques } \\
\text { Hurtubise }\end{array}$ & -2.155 & .208 & -88.41 & 2.41 & $\begin{array}{l}\text { Charles Caleb } \\
\text { Ward }\end{array}$ & -1.655 & .239 & -80.89 & 4.57 \\
\hline $\begin{array}{l}\text { Gershon } \\
\text { Iskowitz }\end{array}$ & -1.641 & .138 & -80.63 & 2.68 & $\begin{array}{l}\text { Esther } \\
\text { Warkov }\end{array}$ & -3.523 & .271 & -97.05 & 0.80 \\
\hline Otto Jacobi & -2.108 & .066 & -87.86 & 0.80 & $\begin{array}{l}\text { Homer } \\
\text { Watson }\end{array}$ & -1.423 & .044 & -75.91 & 1.07 \\
\hline Alex Janvier & -4.330 & .318 & -98.68 & 0.42 & $\begin{array}{l}\text { Gordon } \\
\text { Webber }\end{array}$ & -2.389 & .197 & -90.83 & 1.81 \\
\hline Donald Jarvis & -2.394 & .409 & -90.88 & 3.73 & W.P. Weston & -1.193 & .064 & -69.67 & 1.94 \\
\hline C.W. Jeffreys & -1.570 & .190 & -79.20 & 3.95 & Robert Whale & -2.115 & .098 & -87.93 & 1.19 \\
\hline $\begin{array}{l}\text { Jean-Paul } \\
\text { Jerome }\end{array}$ & -3.097 & .131 & -95.48 & 0.59 & $\begin{array}{l}\text { Joyce } \\
\text { Wieland }\end{array}$ & -2.126 & .317 & -88.07 & 3.78 \\
\hline $\begin{array}{l}\text { Frank } \\
\text { Johnston }\end{array}$ & -0.882 & .030 & -58.61 & 1.26 & $\begin{array}{l}\text { Curtis } \\
\text { Williamson }\end{array}$ & -3.094 & .112 & -95.47 & 0.51 \\
\hline Henri Julien & -1.692 & .289 & -81.58 & 5.32 & W.J. Wood & -2.584 & .268 & -92.46 & 2.02 \\
\hline Denis Juneau & -2.394 & .409 & -90.88 & 3.73 & $\begin{array}{l}\text { Percy } \\
\text { Woodcock }\end{array}$ & -2.175 & .128 & -88.64 & 1.46 \\
\hline Paul Kane & 0.759 & .237 & 113.59 & 50.56 & $\begin{array}{l}\text { Walter } \\
\text { Yarwood }\end{array}$ & -2.142 & .190 & -88.26 & 2.23 \\
\hline
\end{tabular}

Table 4 - Medium/support dummy parameter estimates (oil/canvas excluded) Each parameter measures effect of medium support relative to oil/canvas

\begin{tabular}{lllll}
\hline Medium/support & Parameter & S.E. & $\begin{array}{l}\text { \% Change rel. to } \\
\text { oil/canvas }\end{array}$ & S.E. \\
\hline Oil/panel & -0.171 & .017 & -15.74 & 1.42 \\
Oil/board & -0.240 & .015 & -21.30 & 1.16 \\
Oil/canvas on & -0.206 & .037 & -18.63 & 3.03 \\
board & & & & \\
Oil/cardboard & -0.293 & .030 & -25.41 & 2.22 \\
Oil/paper & -0.435 & .044 & -35.29 & 2.85 \\
Oil/masonite & -0.184 & .033 & -16.83 & 3.20 \\
Acrylic/canvas & -0.251 & .041 & -22.23 & \\
\hline
\end{tabular}

Table 5 - Genre dummy parameter estimates (landscape excluded) Each parameter measures effect of genre relative to landscape

\begin{tabular}{lllll}
\hline Genre & Parameter & S.E. & $\begin{array}{l}\text { \% Change rel. to } \\
\text { Landscape }\end{array}$ & S.E. \\
\hline Genre scene & 0.172 & .017 & 18.75 & 1.99 \\
Still life & 0.063 & .023 & 6.52 & 2.42 \\
Portrait & -0.184 & .030 & -16.84 & 2.50 \\
Abstract & -0.392 & .029 & -32.45 & 1.96 \\
Animal & -0.192 & .036 & -17.44 & 3.01 \\
Figurative & -0.168 & .039 & -15.43 & 3.30 \\
History & -0.434 & .080 & -35.19 & 5.16 \\
\hline
\end{tabular}


Table 6 - Size and dating effects

\begin{tabular}{|c|c|c|c|c|}
\hline (a) Size variable & Parameter & S.E. & $\begin{array}{l}\text { \% Change from } \\
\text { additional } \mathrm{cm}(\mathrm{H} \\
\& \mathrm{~W}) \text { or } \mathrm{cm}^{2} \text { (A) }\end{array}$ & S.E. \\
\hline Height & $1.57 \times 10^{-2}$ & $4.03 \times 10^{-4}$ & 1.58 & 0.04 \\
\hline Width & $1.16 \times 10^{-2}$ & $2.74 \times 10^{-4}$ & 1.17 & 0.03 \\
\hline Area & $-6.77 \times 10^{-5}$ & $3.06 \times 10^{-6}$ & $-6.78 \times 10^{-3}$ & $3.06 \times 10^{-4}$ \\
\hline (b) & Parameter & S.E. & $\begin{array}{l}\text { \% Change rel. to } \\
\text { Undated }\end{array}$ & S.E. \\
\hline Dated & 0.144 & .011 & 15.46 & 1.27 \\
\hline
\end{tabular}

Table 7 - Unit root tests (real, same-currency prices \& returns)

(a) Log index (time trend and 1 lag included)

\begin{tabular}{llll}
\hline Variable & Test & Statistic & $10 \%$ C.V. \\
\hline Mei-Moses index & ADF & -2.29 & -3.16 \\
& PP Z $\alpha$ & -10.81 & -17.39 \\
Canada index & PP Zt & -2.39 & -3.17 \\
& ADF & -1.62 & -3.16 \\
& PP Z $\alpha$ & -8.23 & -17.39 \\
& PP Zt & -1.88 & -3.17 \\
\hline
\end{tabular}

(b) Returns (intercept and 1 lag included)

\begin{tabular}{llll}
\hline Variable & Test & Statistic & $1 \%$ C.V. \\
\hline Mei-Moses index & ADF & -6.26 & -3.57 \\
& PP Z $\alpha$ & -77.90 & -19.80 \\
Canada index & PP Zt & -9.16 & -3.57 \\
& ADF & -4.47 & -3.57 \\
& PP Z $\alpha$ & -75.25 & -19.80 \\
& PP Zt & -9.31 & -3.57 \\
\hline
\end{tabular}

Table 8 - Cointegration tests, real, same-currency prices (residual-based, with time trend in cointegrating regression of Canadian index on Mei-Moses and 1 lag in unit root tests)

\begin{tabular}{lll}
\hline Test & Statistic & $10 \%$ C.V. \\
\hline ADF & -1.31 & -3.61 \\
PP Z $\alpha$ & -8.23 & -22.06 \\
PP Zt & -1.86 & -3.61 \\
\hline
\end{tabular}

Table 9 - Nominal Returns: raw statistics

\begin{tabular}{lll}
\hline Statistic & Mei-Moses & Canada \\
\hline Mean & .0530 & .0367 \\
Standard Deviation & .1329 & .1274
\end{tabular}


Table 10 - Real, Same-Currency Returns: raw statistics

\begin{tabular}{llc}
\hline Statistic & Mei-Moses & Canada \\
\hline Mean & .0303 & .0132 \\
Standard Deviation & .1301 & .1233 \\
Correlation & & .1069 \\
\hline
\end{tabular}

Table 11 - Granger causality statistics, real, same-currency returns (2 lags in VAR) Each statistic is a Wald statistic of the null hypothesis of no Granger-causality, and has a null distribution that is chi-squared with d.f. equal to number of lags

\begin{tabular}{|c|c|c|}
\hline Lags in VAR & Can to International & International to Can \\
\hline 1 & 5.51 & 8.43 \\
\hline 2 & 1.50 & 0.43 \\
\hline 3 & 0.34 & 1.64 \\
\hline 4 & 0.29 & 1.49 \\
\hline 5 & 0.02 & 3.11 \\
\hline 6 & 1.47 & 2.93 \\
\hline
\end{tabular}

Table 12 - Capital Asset Pricing Model (Dependent Variable: Excess returns of DJIA with respect to FF rate)

\begin{tabular}{lccc}
\hline Index & $\begin{array}{c}\text { Intercept } \\
(\text { S.E. }\end{array}$ & $\begin{array}{c}\text { Beta } \\
\text { (S.E.) }\end{array}$ & R-squared \\
\hline Mei-Moses & -0.010 & 0.150 & .019 \\
& $(0.016)$ & $(0.127)$ & .004 \\
Canada (in U.S. \$) & -0.028 & 0.071 & \\
& $(0.016)$ & $(0.133)$ & \\
\hline
\end{tabular}

Table 13 - Macroeconomic Variables to Explain Canadian Art Returns

Dependent Variable: Cdn art

\begin{tabular}{crrr}
\hline Variable & Coefficient & Std. Error & t-Statistic \\
\hline Constant & -0.0275 & 0.0192 & 1.43229 \\
US Art & -0.0189 & 0.1136 & 0.16637 \\
CGDP & 2.49 & 0.849 & 2.9328 \\
CStocks & 0.117 & 0.965 & 0.12124 \\
R-squared & 0.141 & & \\
\hline
\end{tabular}

